\title{
Tracing latitudinal gradient, river discharge and water masses along the Subtropical South American Coast using benthic Foraminifera assemblages
}

\author{
Eichler, PPB. ${ }^{a *}$, Rodrigues, AR. ${ }^{b}$ Eichler, BB. ${ }^{b}$, Braga, ES. ${ }^{b}$ and Campos, EJD. ${ }^{b}$ \\ aPrograma de Pós-Graduação em Geodinâmica e Geofísica - PPGG, Centro de Ciências Exatas e da Terra, Universidade \\ Federal do Rio Grande do Norte - UFRN, Campus Universitário, Lagoa Nova, CEP 59072-970, Natal, RN, Brazil \\ ' Instituto Oceanográfico, Universidade de São Paulo - USP, Praça do Oceanográfico, 191, \\ Cidade Universitária, CEP 05508-120, São Paulo, SP, Brazil \\ *e-mail: patriciaeichler@gmail.com \\ Received February 13, 2012 - Accepted July 23, 2012 - Distributed August 31, 2012
}

(With 6 figures)

\begin{abstract}
More than $30 \%$ of Buccella peruviana (D'Orbigny), Globocassidulina crassa porrecta (Earland \& HeronAllen), Cibicides mackannai (Galloway \& Wissler) and C. refulgens (Montfort) indicate the presence of cold Sub Antarctic Shelf Water in winter, from 33.5 to $38.3^{\circ} \mathrm{S}$, deeper than $100 \mathrm{~m}$, in the southern part of the study area. In summer, the abundance of this association decreases to less than $15 \%$ around $37.5-38.9^{\circ} \mathrm{S}$ where two species (Globocassidulina subglobosa (Brady), Uvigerina peregrina (Cushman) take over. G. subglobosa, U. peregrina, and Hanzawaia boueana (D'Orbigny) are found at $27-33^{\circ} \mathrm{S}$ in both seasons in less than $55 \mathrm{~m}$ deep in the northern part, and are linked with warm Subtropical Shelf Water and Tropical Water. Freshwater influence was signalized by high silicate concentration and by the presence of Pseudononion atlanticum (Cushman), Bolivina striatula (Cushman), Buliminella elegantissima (D’Orbigny), Bulimina elongata (D’Orbigny), Elphidium excavatum (Terquem), E. poeyanum (D’Orbigny), Ammobaculites exiguus (Cushman \& Brönnimann), Arenoparrella mexicana (Kornfeld), Gaudryina exillis (Cushman \& Brönnimann), Textularia earlandi (Parker) and thecamoebians in four sectors of the shelf. The presence of Bulimina marginata (D'Orbigny) between $34.1-32.8^{\circ} \mathrm{S}$ in the winter and $34.2-32.7^{\circ} \mathrm{S}$ in the summer indicates that the influence of the Subtropical Shelf Front on the sediment does not change seasonally, otherwise, the presence of Angulogerina angulosa (Williamson) in the winter, only in Mar del Plata $\left(38.9^{\circ} \mathrm{S}\right)$, show that Malvinas currents are not influencing the sediment in the summer.
\end{abstract}

Keywords: foraminifera diversity, subantarctic and subtropical shelf water, subtropical shelf front, freshwater influence.

\section{Registro do gradiente latitudinal, de descargas de rios e de massas de água ao longo da costa subtropical da América do Sul, utilizando-se associações de foraminíferos bentônicos}

\begin{abstract}
Resumo
Mais de 30\% de dominância de Buccella peruviana, Globocassidulina crassa porrecta, Cibicides mackannai e C. refulgens indica a presença de água fria da Corrente Subantártica de plataforma no inverno entre 33,5-38,3 $\mathrm{S}$, principalmente no setor sul da area estudada. No verão, no entanto, nas estações mais profundas do que $100 \mathrm{~m}$, a abundância dessa associação diminui para menos de $15 \%$ em torno de $37,5-38,9^{\circ} \mathrm{S}$, onde duas espécies (Globocassidulina subglobosa e Uvigerina peregrina) dominam. G. subglobosa, U. peregrina e Hanzawaia boueana são encontradas principalmente em menos de $55 \mathrm{~m}$ de profundidade na parte norte da área $\left(27-33^{\circ} \mathrm{S}\right)$, tanto no inverno como no verão, e estão relacionadas com águas mais quentes de Plataforma Subtropical e de Água Tropical. Em quatro áreas da plataforma continental, foi observada a influência de aporte continental com alta concentração de silicato no sedimento. Essa influência é detectada pela presença de Pseudononion atlanticum, Bolivina striatula, Buliminella elegantissima, Bulimina elongata, Elphidium excavatum, E. poeyanum, Ammobaculites exiguus, Arenoparrella mexicana, Gaudryina exillis, Textularia earlandi e tecamebas. A presença de Bulimina marginata entre $34,1-32,8^{\circ} \mathrm{S}$ no inverno e $34,2-32,7^{\circ} \mathrm{S}$ no verão indica que a influência da Frente Subtropical Plataforma sobre os sedimentos não muda sazonalmente; mas, por outro lado, a presença de Angulogerina angulosa no inverno, apenas na estação mais profunda de Mar del Plata $\left(38,9^{\circ} \mathrm{S}\right)$, mostra que as correntes das Malvinas não estão influenciando o sedimento dessa região no verão.
\end{abstract}

Palavras-chave: diversidade de foraminíferos, água de plataforma subantártica e subtropical, frente subtropical de plataforma, influência de água doce. 


\section{Introduction}

The factors that control the latitude-diversity of benthic Foraminifera are still unclear. Some researchers have pointed out the importance of historical climatic stability, productivity, and amount of energy of oceanic environments (Gaston and Blackburn, 2000). Others defend the importance of biological interactions (Roughgarden, 1986). However, the most acceptable cause for latitudinal gradient of regional species richness is considered to be variation in the rates of extinction and speciation, and the history of secular dispersal (Huston, 1994); all of these variations reflect differences in biogeographically or evolutionary processes along latitude and can be detected by Foraminifera analysis. Besides the macro-scale distribution, the influence of freshwater runoff and oceanic fronts can disrupt these patterns providing interesting phenomena to be explored. Here we will draw on sediment and water samples taken on the western south Atlantic continental shelf between $27-39.9^{\circ} \mathrm{S}$, a region strongly influenced by the discharges of the Plata River and Patos Lagoon.

A pioneering study carried through by Boltovskoy et al. (1980) in that region made possible the identification of the large-scale Foraminiferal distribution in the South Atlantic, associating it to the great systems of oceanic circulation, Brazil Current (BC) and Malvinas Current (MC) (Figure 1). Our study, however, focuses on the coastal environments influenced mainly by freshwater runoff and coastal water masses interactions that will be described below.

Miranda (1972) first described the basic signature of four water masses between latitudes of $29^{\circ} \mathrm{S}$ and $35^{\circ}$ $\mathrm{S}$ : Estuarine water from Plata River, SubAntarctic Water $(33.7<\mathrm{S}<34.15)$, SubTropîcal Water and Tropical water $(\mathrm{S}>36)$, the first two being transported by Malvinas Currents and the last two being transported by Brazil Current.

The Brazil current is a salty and warm $\left(\mathrm{T}>20^{\circ} \mathrm{C}, \mathrm{S}>36.4\right)$ western boundary current that flows southward as part of the subtropical gyre of the South Atlantic Ocean (Silveira et al., 2000; Stramma and England, 1999; Castro and Miranda, 1998). The relatively cold and fresh Malvinas current (MC) originates as a branch of the Antarctic Circumpolar current which enters the Argentine Basin after Drake passage and takes a northeastward trajectory following the Patagonia Shelf break, until it reaches the Brazil current offshore of the Plata estuary. Once the Brazil and Malvinas Current meet, they flow eastward in a region known as Brazil Malvinas Confluence. Due to vorticity constraints, after the confluence the two currents hardly mix and continue eastward as different entities: the BC integrating the South Atlantic current (the lower bound of the subtropical gyre), and the MC rejoining the Antarctic Circumpolar Current (Campos and Olson, 1991).

In terms of temperature and salinity, off the Southwest Atlantic continental margin, two distinct water masses are identified, the Subantarctic Shelf Water (SASW) where $\mathrm{T}<15{ }^{\circ} \mathrm{C}$ and $33.7<\mathrm{S}<34.15$ and the Subtropical Shelf Water (STSW), where $\mathrm{T}>12^{\circ} \mathrm{C}$ and $\mathrm{S}>34.5$. Especially in the summer, pure SASW located below the seasonal thermocline is characterized by waters colder than $16{ }^{\circ} \mathrm{C}$ (Piola et al., 2008). Subantarctic Shelf Water originates by dilution of Subantarctic Water, primarily in the southeast Pacific, due to excess precipitation and continental runoff. The Subtropical Shelf Water is modified South Atlantic Central Water diluted by continental runoff from the coast of Brazil (Piola et al., 2000, 2008). In addition, substantial dilution of the upper shelf waters takes place at the mouth of Plata River (at $36^{\circ} \mathrm{S}$ ) and, in a lesser extent, at the Patos-Mirim Lagoon (at $32^{\circ} \mathrm{S}$ ). In addition to fresh water, the Plata and Patos Lagoon runoff also brings to the continental shelf a large amount of geochemical and mineralogical constituents, which are eventually deposited on the ocean floor and greatly impacting the biogeochemical processes in the entire water column (Campos et al., 2008).

Both Plata River and the Patos Lagoon outflows form a low-salinity tongue that caps the shelf water, leading to a salinity decrease to values lower than 30 . Observations and numerical models suggest that the low-salinity tongue extends northward over the shelf penetrating farther north in winter than in summer (Campos et al., 1996; Pimenta, 2001; Pimenta et al., 2005; Piola et al., 2005). The extent of the low-salinity water has a strong impact on the vertical stratification and in the interface sediment-water as well. There is little indication of mixing between Subantarctic Shelf Water and Subtropical Shelf Water. Therefore, an intense temperature, salinity, and nutrient front separate these water masses. The front is oriented along the northsouth direction, located on average near the $50 \mathrm{~m}$ isobath at $32^{\circ} \mathrm{S}$ and extends southward toward the shelf break near $36^{\circ} \mathrm{S}$. Between $32-34^{\circ} \mathrm{S}$ the Subtropical Shelf Front follows the 100 to $200 \mathrm{~m}$ isobaths and separates Subantarctic Shelf Water from the oceanic South Atlantic Central Water (Piola et al., 2000).

The dynamics of the South Atlantic Ocean is complex and studies to better understand its oceanography are fundamental to predict future global changes, factors as temperature, salinity and nutrients are good indicators but the application of environmental proxies are also important.

The present work focuses on the indicator species of different water masses describing the complex relations among biological, physical and geochemical variables in the sediment-water interface $(1 \mathrm{~cm})$. The aim is to investigate the total Foraminiferal assemblages in surface sediments in winter and in summer samples that were collected in a shelf region bound offshore by the Brazil/Malvinas current system and inshore by the freshwater source of Plata using a bottom snapper up to $250 \mathrm{~m}$ on eleven longitudinal transects. The specific questions in this work were to examine: 1) whether there is a latitudinal gradient of distribution and how they vary on space, and 2) the influence of the Subtropical Shelf Front in the interface sediment-water based on the Foraminiferal dynamics.

The first question is associated with the nature and extent of latitudinal gradients of species richness in the oceans. The last addressed question is whether there are any latitudinal gradients of species diversity regarding the 


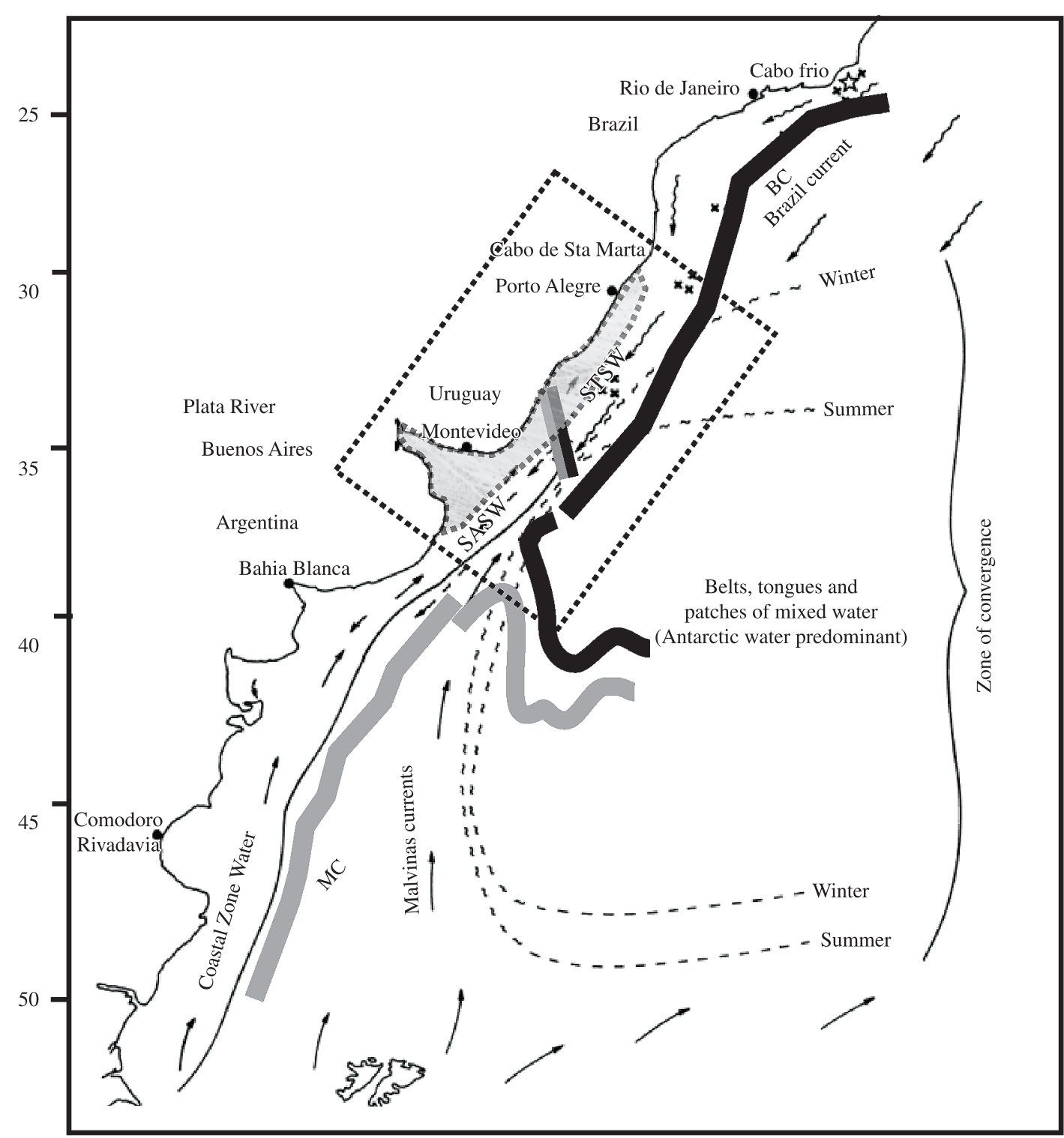

Figure 1. Dynamics of water masses and currents in the South Atlantic (Modified of Boltovskoy et al., 1980 and Piola et al., 2000). BC: Brazil Current, MC: Malvinas Currents, STSW: Subtropical Shelf Water, SASW: Sub Antartic Shelf Water. The area of average influence of the plume of the Plata River during the winter, is indicated by the gray shadow. The dotted rectangle denotes the region of the present study.

interaction of water masses and the migration (or not) of the Subtropical Shelf Front, and its significant seasonal movement back and forth.

\section{Material and Methods}

\subsection{Sample collection}

During two oceanographic cruises a total of 120 surface sediment samples for benthic analyses were collected in austral winter (August, 20 $0^{\text {th }}$ to September, $2^{\text {nd }} 2003$ ) and in austral summer (February, $1^{\text {st }}$ to $19^{\text {th }} 2004$ ). Sixty-four samples were collected in winter; and fifty-six samples in summer, using a bottom snapper in eleven longitudinal transects in the depths of 10 and $250 \mathrm{~m}$ (Figure 2). The position of the samples on transects can be visualized from south to north: 1) Mar del Plata; 2) Punta Medanos; 3) Plata River; 4) Punta del Este; 5) Punta del Diablo; 6) Albardão; 7) Rio Grande; 8) Solidão; 9) Torres; 10) Santa Marta and 11) Itajaí (Figure 2).

A transformation in the geographic coordinates (latitude and longitude) of the data was carried through to better allow visualization of the results. The coordinates of the shoreline and the stations of collection were converted for coordinate UTM (Universal Transverse Mercator) 
according to ellipsoid WGS-84, where the distances of latitude and longitude were transformed for kilometers. Later, the same data was rotated in 35 degrees in relation to the north. This modification can be visualised in all the figures (from Figure 2).

\subsection{Water samples}

Samples of bottom or near-bottom water were taken from most of the stations for nutrient analysis; a surfacewater sample (but no bottom-water sample) was taken at 90 in summer. Temperature $\left({ }^{\circ} \mathrm{C}\right)$ and salinity (PSU) were recorded at each station, using a CTD from SeaBird Electronics model 911.

The samples for dissolved oxygen and nutrients were collected in rosette bottles. These data analysis from the entire water column are described in Braga et al. (2008), but in our work we have used preferentially the bottom water information. Dissolved oxygen $\left(\mathrm{mLL}^{-1}\right)$ was first extracted and measured by the Winkler procedure using an automated titration method (Grasshoff et al., 1983).

The dissolved nutrients evaluated were: silicate, nitrite, and nitrate $(\mu \mathrm{M})$. The dissolved nutrients were filtered through Whatman GF/F membranes. The samples were frozen $\left(-20^{\circ} \mathrm{C}\right)$ and the analyses of nitrate and nitrite were performed using an automated system (AutoAnalyzer II - Bran-Luebbe), following the procedure in Grasshoff et al. (1983). The silicate analyses were done by spectrophotometric method. The suspended particulate matter (SM) (mg/L), and the organic matter $(\mathrm{OM})(\%)$ in the bottom water was analyzed gravimetrically (Strickland and Parsons, 1972), this methodology consists of $500 \mathrm{~mL}$ of water filtered through Whatman GF/F membrane and the dry content weighted (SM), and burnt in a $450{ }^{\circ} \mathrm{C}$ oven and, by the difference of the SM weight and the burnt membrane, the OM could be calculated.

\subsection{Field and laboratory procedures for Foraminiferal study}

After collection, the uppermost layer of the sediment (about $1 \mathrm{~cm}$ ) was removed and stored in a mixture of $30 \%$ alcohol and buffered $\left(\mathrm{Na}_{2} \mathrm{~B}_{4} \mathrm{O}_{7} \cdot 10 \mathrm{H}_{2} \mathrm{O}\right)$ rose Bengal stain ( $1 \mathrm{~g}$ of rose Bengal in $1 \mathrm{~L}$ of distilled water). Rose Bengal was used for staining live Foraminifera to observe if the live data shows the same seasonal patterns as the total data trying to verify the consistency in the latitudinal shift of species. Faunal analysis followed standard procedures (Eichler et al., 2007), where a fixed volume of $10 \mathrm{~cm}^{3}$ of sediment was washed through a sieve with $0.062 \mathrm{~mm}$
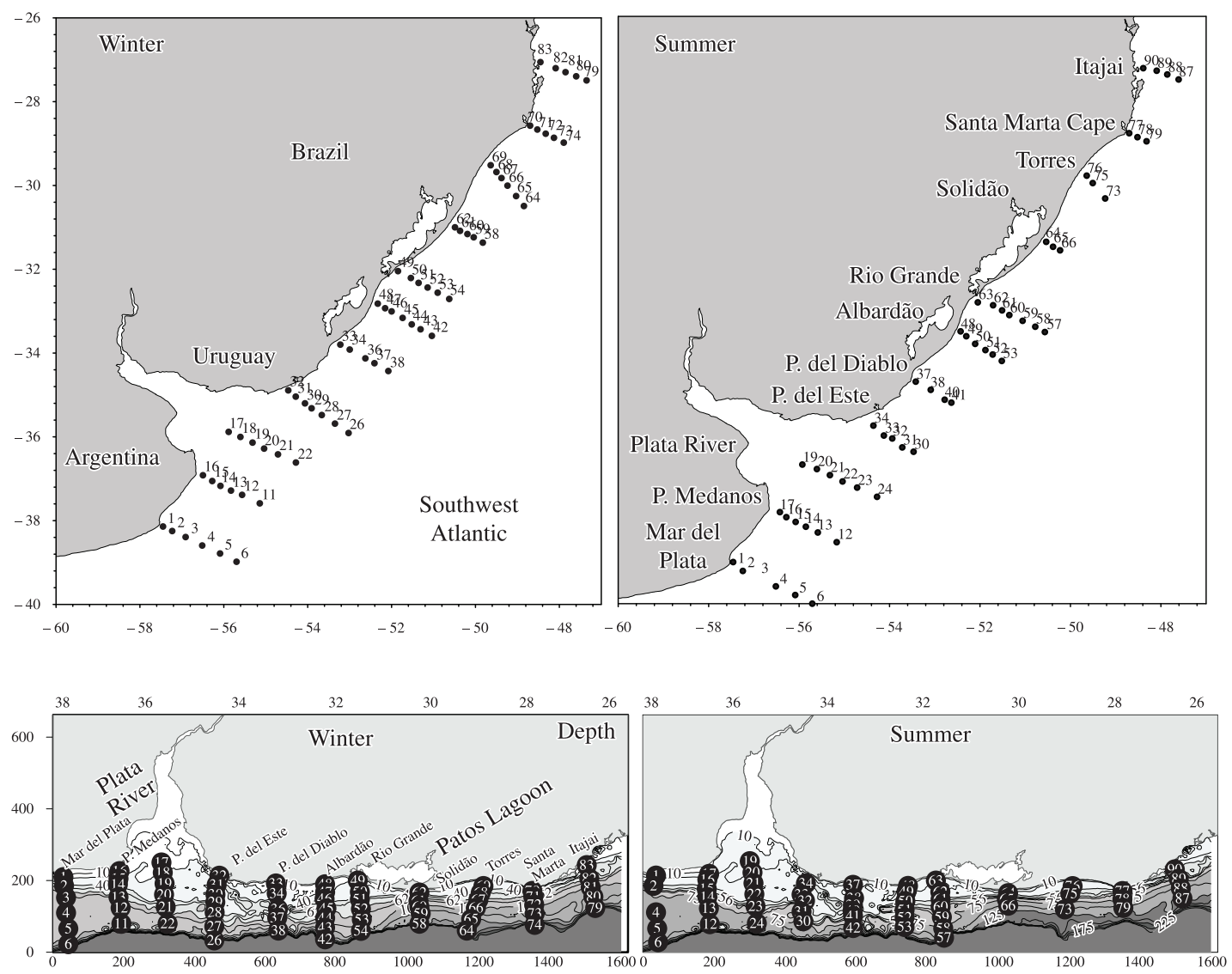

Figure 2. Position of the samples on transects in the winter and summer and the study area (in $\mathrm{km}$ ) and bathimetric map for the 11 transects winter and summer (dotted rectangle in the Figure 1). It is worth mentioning that the X and Y axis represent the distance in kilometres obtained from latitude and longitude. 
openings. Using a dry microsplitter (model from Green Geological Services), the residue was split into subsamples of approximately 500 specimens (live and dead) and the taxa were counted. All specimens were counted when the number of foraminifers in a sample was less than 500 . Species identification and counting of dry specimens were done under an optical microscope (magnification: $68 \times)$. Scanning electron micrographs were obtained with a JSM-6.600 Geol-Scanner to help with some problematic identification and to illustrate the manuscript.

\subsection{Data analyses}

The identification of the Foraminifera species was done in accordance with the Catalogue of Foraminifera (Ellis and Messina, 1940). The individuals were summed to get the absolute frequency of individuals (living + dead) per station. The relative frequency of the species was calculated from the total absolute frequency. Data on relative abundance is available on supplementary data.

Shannon-Wiener diversity was determined by PRIMER, University of Plymouth software (Clarke and Warwick, 1994), using the Equation 1.

Shannon Wiener diversity $H^{\prime}=-\sum_{i=1}^{R} p_{i} \log p_{i}$

Distribution maps: Relative frequency of the main Foraminifera species and environmental data (salinity, temperature, dissolved oxygen, and nutrients) has generated contour maps using the Surfer 8 (Golden software) to illustrate and facilitate the visualization of the data.

\section{Results}

The abundance, richness, diversity and content of calcareous, agglutinated and planktonic Foraminifera in the winter and summer samples can be seen in Tables 1 and 2 . Table 3 is a list of all found species during the winter and summer. As the abundance of living specimens is lower than dead and in many samples living specimens were not found, the data set chosen for the whole manuscript is based on total relative frequency data (dead plus live).

\subsection{Biological parameters}

The main species found were the benthic calcareous: Globocassidulina subglobosa, Uvigerina peregrina, Bulimina marginata, Buccella peruviana and Bolivina striatula. The agglutinated species Textularia earlandi and Arenoparella mexicana, and the planktonic Globigerinoides rubber and Globorotalia menardii were also frequent.

During the winter it is verified the presence of 68 Rotaliida species, 19 agglutinated species, 12 planktonic species, and some thecamoebian tests. In the summer, the number of total species decreased and it is observed 57 Rotaliida species, 15 agglutinated species, 4 species of planktonics, and also, some thecamoebian tests.
Figures 3 to 5 show distribution maps of relative frequency of some Foraminifera dominant species and their relation with water masses dynamics in the region.

Figure 3 presents Bolivina striatula, Buliminella elegantissima, Bulimina elongata, Elphidium excavatum, Elphidium poeyanum, and Pseudononion atlanticum as Continental Water species (CW). The CW is the oceanic saline water combined with cooland less saline water deriving of the continental draining. In a generalised manner, such species are limited by depth, occurring close to continental water discharge.

Bolivina striatula were found in the shallowest stations of transects between the Plata River $\left(35.8^{\circ} \mathrm{S}\right)$ and Rio Grande $\left(31.5^{\circ} \mathrm{S}\right)$. In the winter, Bolivina striatula also presents peak of occurrence $(16 \%<\mathrm{x}<40 \%)$ in Transects 4,6 and 7 (Punta del Este, $34.8^{\circ} \mathrm{S}$; Albardão, $32^{\circ} \mathrm{S}$; and Rio Grande, $31.5^{\circ} \mathrm{S}$ ); and in the summer, the occurrence is concentrated mainly in the Plata River (40\%).

In the winter, Buliminella elegantissima presents peak of dominance $(35.3 \%)$ in Punta del Diablo $\left(33^{\circ} \mathrm{S}\right)$ and Albardão (33.7\%) $\left(32^{\circ} \mathrm{S}\right)$, and in the summer, the occurrence of peaks increases in the Albardão (40\%), indicating the presence of continental water in this region.

In the winter, Bulimina elongata presents peak of abundance (17.4\%) in Punta del Este, and in the summer, the peak occurs in the Plata River (30\%). Elphidium excavatum, in the winter, presents peak of occurrence in the shallowest stations of Punta del Diablo (61\%), Plata River (16.4\%), and Rio Grande (27.6\%). In the summer, the peaks decrease and are concentrated in Punta Medanos $(6.9 \%)\left(36.5^{\circ} \mathrm{S}\right)$. Elphidium poeyanum presents peak of occurrence in the winter (44.4\%) in Albardão (shallow stations, 11,7 and $20 \mathrm{~m}$ depth, respectively), and in the summer, the abundance of this species in the shallowest stations occurs in Punta del Diablo (40.3\%), Albardão (43.5\%) and Rio Grande (49.1\%). In the winter, Pseudononion atlanticum, presents three peaks of occurrence in Punta del Este (25.8\%), Rio Grande $(33.3 \%)$, and Torres $(67.7 \%),\left(28.5^{\circ} \mathrm{S}\right)$, mainly in the shallowest stations (less than $50 \mathrm{~m}$ ), and in the summer, the peak of occurrence is concentrated in Rio Grande (40\%).

In Figure 4a the typical observed slope species are Angulogerina angulosa, Globocassidulina crassa porrecta, Cibicides mackannai, and Cibicides refulgens. These species show peak of abundance in the southern transects. Angulogerina angulosa (51\%) occurs only in the winter in Mar del Plata $\left(38^{\circ} \mathrm{S}\right)$ (117 $\mathrm{m}$ of depth), and for being the dominant species in the Malvinas Current (Boltovskoy and Wright, 1959) and to be characteristic of deeper places (upper slope) (Harloff and Mackensen, 1997) the occurrence of this species indicates the presence of the Malvinas Current in this region.

In Figure 4b, the Subtropical Shelf Water (STSW) has Globocassidulina subglobosa as related species and Uvigerina peregrina as related species of the South Atlantic Central Water (SACW). Hanzawaia boueana is related to the Tropical Water under the influence of the Brazil current. Globocassidulina subglobosa occurs mainly to 
Table 1. Richness and abundance of living and total Foraminifera in each sample collected during the austral winter of 2003. The Shannon-Wiener diversity of total Foraminifera and content of calcareous, agglutinated, planktonic specimens and thecamebians.

\begin{tabular}{|c|c|c|c|c|c|c|c|c|c|c|}
\hline \multirow{2}{*}{ Winter } & \multirow{2}{*}{ Stations } & \multicolumn{2}{|c|}{ Richness } & \multicolumn{2}{|c|}{ Abundance } & \multirow{2}{*}{$\begin{array}{l}\text { Diversity } \\
\text { H'(log10) }\end{array}$} & \multirow{2}{*}{$\begin{array}{c}\text { Calcareous } \\
(\%)\end{array}$} & \multirow{2}{*}{$\begin{array}{c}\text { Agglutinated } \\
(\%)\end{array}$} & \multirow{2}{*}{$\begin{array}{c}\text { Planktonic } \\
(\%)\end{array}$} & \multirow{2}{*}{$\begin{array}{c}\text { Thecamoebians } \\
(\%)\end{array}$} \\
\hline & & Live & Total & Live & Total & & & & & \\
\hline \multirow{6}{*}{ 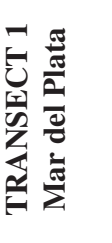 } & 1 & 6 & 12 & 28 & 65 & 0.910 & 90.8 & 9.2 & 0.0 & 0.0 \\
\hline & 2 & 7 & 32 & 13 & 493 & 1.186 & 94.7 & 5.3 & 0.0 & 0.0 \\
\hline & 3 & 5 & 21 & 55 & 1068 & 0.717 & 73.7 & 26.3 & 0.0 & 0.0 \\
\hline & 4 & 3 & 11 & 18 & 249 & 0.792 & 57.4 & 42.6 & 0.0 & 0.0 \\
\hline & 5 & 5 & 13 & 33 & 545 & 0.607 & 84.2 & 5.9 & 9.9 & 0.0 \\
\hline & 6 & 0 & 14 & 0 & 3056 & 0.713 & 98.7 & 1.3 & 0.0 & 0.0 \\
\hline \multirow{6}{*}{ 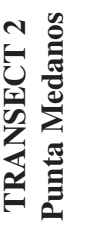 } & 11 & 2 & 11 & 6 & 159 & 0.714 & 85.5 & 13.2 & 0.0 & 1.3 \\
\hline & 12 & 1 & 14 & 2 & 127 & 0.845 & 75.6 & 24.4 & 0.0 & 0.0 \\
\hline & 13 & 6 & 30 & 90 & 2382 & 0.865 & 84.4 & 13.9 & 1.8 & 0.0 \\
\hline & 14 & 10 & 23 & 18 & 186 & 1.006 & 97.3 & 2.7 & 0.0 & 0.0 \\
\hline & 15 & 1 & 11 & 1 & 77 & 0.861 & 85.7 & 14.3 & 0.0 & 0.0 \\
\hline & 16 & 2 & 9 & 2 & 23 & 0.877 & 69.6 & 30.4 & 0.0 & 0.0 \\
\hline \multirow{7}{*}{ 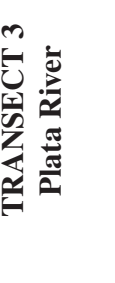 } & 17 & 4 & 9 & 42 & 145 & 0.689 & 99.3 & 0.7 & 0.0 & 0.0 \\
\hline & 18 & 5 & 16 & 11 & 73 & 1.082 & 97.3 & 2.7 & 0.0 & 0.0 \\
\hline & 19 & 4 & 12 & 6 & 55 & 0.772 & 94.5 & 5.5 & 0.0 & 0.0 \\
\hline & 20 & 2 & 16 & 3 & 61 & 1.076 & 88.5 & 11.5 & 0.0 & 0.0 \\
\hline & 21 & 5 & 10 & 6 & 24 & 0.765 & 95.8 & 4.2 & 0.0 & 0.0 \\
\hline & 22 & 3 & 12 & 80 & 800 & 0.478 & 87.0 & 13.0 & 0.0 & 0.0 \\
\hline & 26 & 3 & 25 & 450 & 30300 & 1.027 & 78.7 & 21.0 & 0.0 & 0.3 \\
\hline \multirow{6}{*}{ 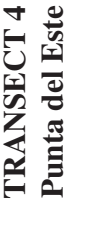 } & 27 & 3 & 15 & 32 & 332 & 0.771 & 62.7 & 31.9 & 0.0 & 5.4 \\
\hline & 28 & 0 & 16 & 0 & 120 & 0.827 & 89.2 & 8.3 & 2.5 & 0.0 \\
\hline & 29 & 0 & 2 & 0 & 2 & 0.301 & 50.0 & 50.0 & 0.0 & 0.0 \\
\hline & 30 & 2 & 9 & 20 & 115 & 0.785 & 95.7 & 0.0 & 0.0 & 4.3 \\
\hline & 31 & 3 & 13 & 15 & 639 & 0.764 & 97.7 & 2.3 & 0.0 & 0.0 \\
\hline & 32 & 2 & 7 & 5 & 31 & 0.580 & 96.8 & 0.0 & 0.0 & 3.2 \\
\hline \multirow{5}{*}{ 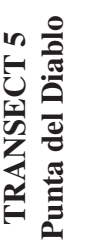 } & 33 & 4 & 9 & 41 & 150 & 0.662 & 98.0 & 2.0 & 0.0 & 0.0 \\
\hline & 34 & 2 & 5 & 2 & 13 & 0.512 & 100.0 & 0.0 & 0.0 & 0.0 \\
\hline & 36 & 3 & 17 & 12 & 300 & 0.895 & 96.0 & 4.0 & 0.0 & 0.0 \\
\hline & 37 & 4 & 12 & 16 & 194 & 0.587 & 94.8 & 5.2 & 0.0 & 0.0 \\
\hline & 38 & 0 & 22 & 0 & 1976 & 0.795 & 93.5 & 2.0 & 4.0 & 0.4 \\
\hline \multirow{7}{*}{ 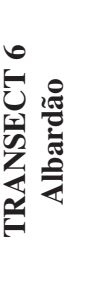 } & 42 & 0 & 17 & 0 & 4630 & 0.965 & 99.8 & 0.2 & 0.0 & 0.0 \\
\hline & 43 & 0 & 21 & 0 & 3937 & 0.884 & 99.8 & 0.2 & 0.0 & 0.0 \\
\hline & 44 & 0 & 19 & 0 & 710 & 0.959 & 98.3 & 1.1 & 0.0 & 0.6 \\
\hline & 45 & 0 & 12 & 0 & 720 & 0.795 & 98.3 & 1.7 & 0.0 & 0.0 \\
\hline & 46 & 0 & 20 & 0 & 1316 & 0.990 & 99.4 & 0.6 & 0.0 & 0.0 \\
\hline & 47 & 0 & 4 & 0 & 36 & 0.553 & 77.8 & 22.2 & 0.0 & 0.0 \\
\hline & 48 & 0 & 8 & 0 & 95 & 0.627 & 100.0 & 0.0 & 0.0 & 0.0 \\
\hline \multirow{6}{*}{ 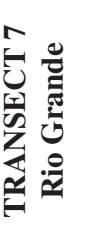 } & 49 & 4 & 8 & 15 & 58 & 0.778 & 98.3 & 1.7 & 0.0 & 0.0 \\
\hline & 50 & 2 & 3 & 2 & 3 & 0.477 & 100.0 & 0.0 & 0.0 & 0.0 \\
\hline & 51 & 0 & 27 & 0 & 3040 & 0.971 & 95.8 & 1.6 & 2.6 & 0.0 \\
\hline & 52 & 1 & 9 & 12 & 948 & 0.518 & 97.5 & 0.0 & 2.5 & 0.0 \\
\hline & 53 & 0 & 15 & 0 & 3906 & 0.730 & 98.6 & 1.4 & 0.0 & 0.0 \\
\hline & 54 & 0 & 28 & 0 & 5016 & 0.798 & 83.6 & 0.3 & 16.1 & 0.0 \\
\hline \multirow{5}{*}{ 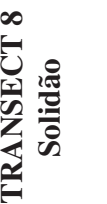 } & 58 & 1 & 26 & 12 & 5460 & 0.494 & 98.5 & 1.5 & 0.0 & 0.0 \\
\hline & 59 & 1 & 16 & 30 & 10230 & 0.451 & 96.5 & 0.0 & 3.5 & 0.0 \\
\hline & 60 & 0 & 14 & 0 & 5031 & 0.551 & 100.0 & 0.0 & 0.0 & 0.0 \\
\hline & 61 & 1 & 17 & 324 & 8424 & 0.883 & 98.7 & 1.3 & 0.0 & 0.0 \\
\hline & 62 & 0 & 5 & 0 & 2664 & 0.381 & 100.0 & 0.0 & 0.0 & 0.0 \\
\hline
\end{tabular}


Table 1. Continued...

\begin{tabular}{|c|c|c|c|c|c|c|c|c|c|c|}
\hline \multirow{2}{*}{ Winter } & \multirow{2}{*}{ Stations } & \multicolumn{2}{|c|}{ Richness } & \multicolumn{2}{|c|}{ Abundance } & \multirow{2}{*}{$\begin{array}{l}\text { Diversity } \\
\text { H'}^{\prime}(\log 10)\end{array}$} & \multirow{2}{*}{$\begin{array}{c}\text { Calcareous } \\
(\%)\end{array}$} & \multirow{2}{*}{$\begin{array}{c}\text { Agglutinated } \\
(\%)\end{array}$} & \multirow{2}{*}{$\begin{array}{c}\text { Planktonic } \\
(\%)\end{array}$} & \multirow{2}{*}{$\begin{array}{c}\text { Thecamoebians } \\
(\%)\end{array}$} \\
\hline & & Live & Total & Live & Total & & & & & \\
\hline \multirow{6}{*}{ 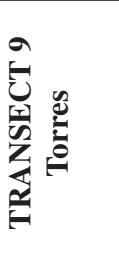 } & 64 & 0 & 19 & 0 & 16200 & 0.921 & 77.8 & 5.9 & 16.3 & 0.0 \\
\hline & 65 & 0 & 22 & 0 & 69255 & 0.543 & 99.3 & 0.7 & 0.0 & 0.0 \\
\hline & 66 & 0 & 9 & 0 & 370 & 0.562 & 98.6 & 1.4 & 0.0 & 0.0 \\
\hline & 67 & 0 & 16 & 0 & 1045 & 0.900 & 99.0 & 1.0 & 0.0 & 0.0 \\
\hline & 68 & 0 & 16 & 0 & 7995 & 0.562 & 100.0 & 0.0 & 0.0 & 0.0 \\
\hline & 69 & 0 & 12 & 0 & 665 & 0.930 & 96.2 & 3.8 & 0.0 & 0.0 \\
\hline \multirow{5}{*}{ 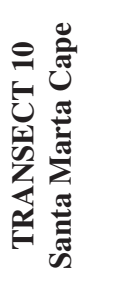 } & 70 & 0 & 24 & 0 & 4664 & 0.998 & 98.3 & 1.7 & 0.0 & 0.0 \\
\hline & 71 & 0 & 11 & 0 & 1368 & 0.560 & 100.0 & 0.0 & 0.0 & 0.0 \\
\hline & 72 & 0 & 13 & 0 & 2330 & 0.429 & 99.1 & 0.9 & 0.0 & 0.0 \\
\hline & 73 & 0 & 24 & 0 & 3106 & 1.120 & 93.0 & 7.0 & 0.0 & 0.0 \\
\hline & 74 & 0 & 19 & 0 & 8685 & 1.054 & 92.2 & 7.8 & 0.0 & 0.0 \\
\hline \multirow{5}{*}{ 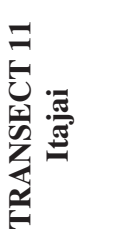 } & 79 & 0 & 26 & 0 & 10215 & 1.011 & 95.6 & 4.4 & 0.0 & 0.0 \\
\hline & 80 & 0 & 23 & 0 & 14760 & 0.975 & 95.7 & 4.3 & 0.0 & 0.0 \\
\hline & 81 & 0 & 12 & 0 & 1935 & 0.663 & 98.7 & 1.3 & 0.0 & 0.0 \\
\hline & 82 & 0 & 18 & 0 & 2695 & 0.772 & 100.0 & 0.0 & 0.0 & 0.0 \\
\hline & 83 & 0 & 29 & 0 & 17440 & 1.101 & 99.0 & 1.0 & 0.0 & 0.0 \\
\hline
\end{tabular}

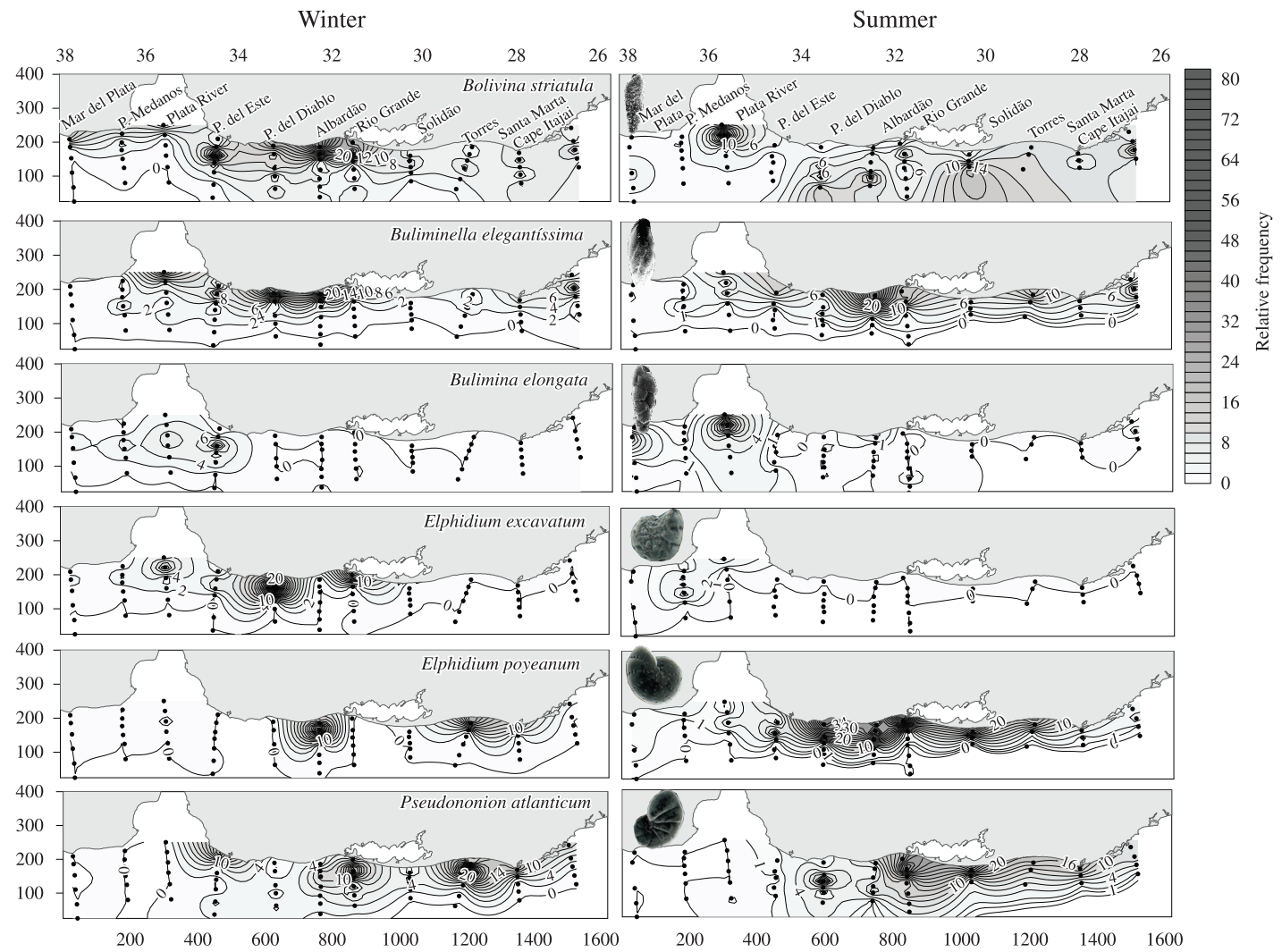

Figure 3. Continental water species $(\mathrm{CW})$. It is worth mentioning that the $\mathrm{X}$ and $\mathrm{Y}$ axis represent the distance in Kilometers obtained from latitude and longitude. 


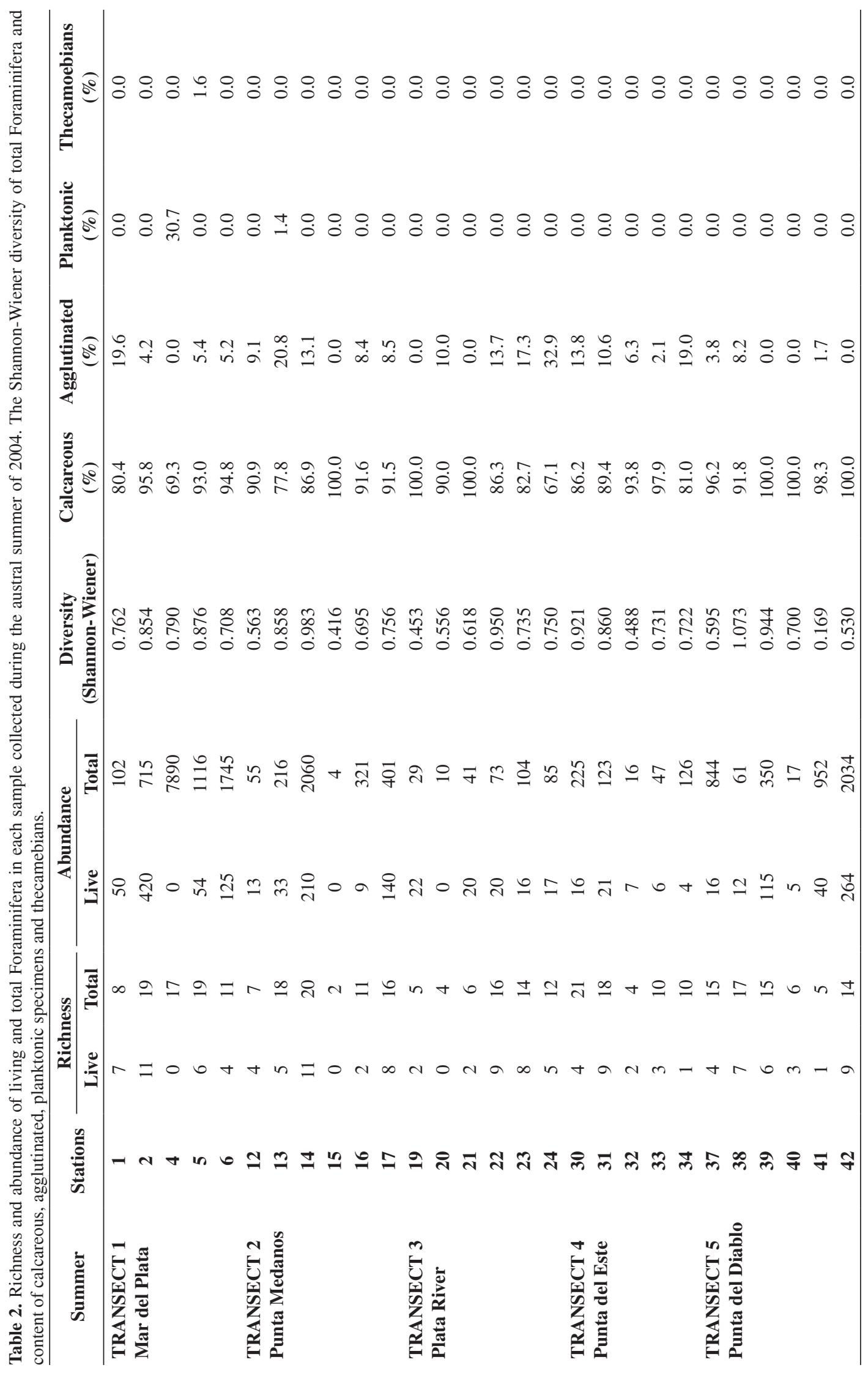




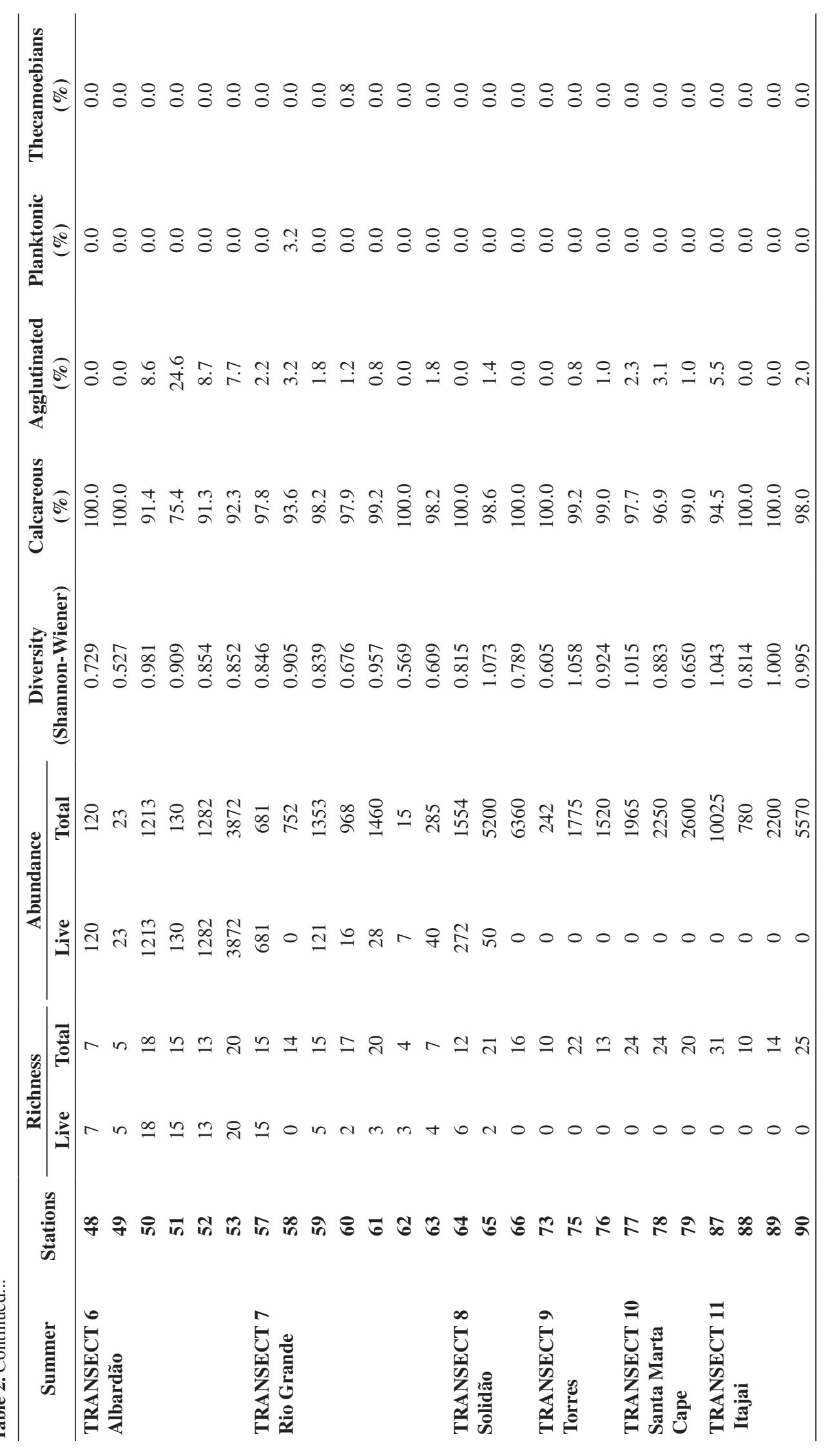


Table 3. List of the Foraminifera species found during the study.

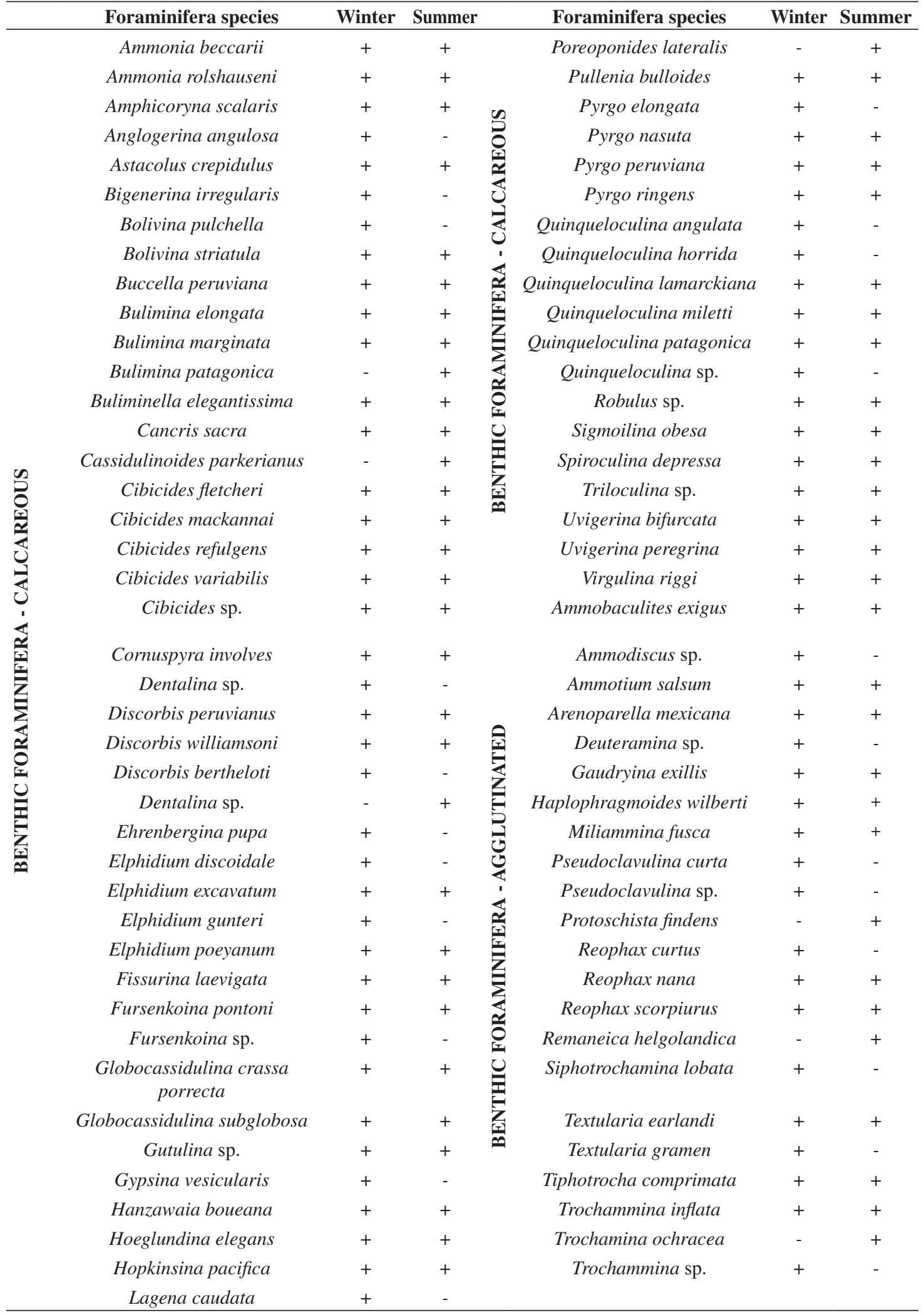


Table 3. Continued...

\begin{tabular}{|c|c|c|c|c|c|c|c|}
\hline & Foraminifera species & Winter & Summer & & Foraminifera species & Winter & Summer \\
\hline \multirow{12}{*}{ 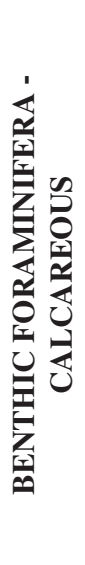 } & Lagena digitale & + & - & \multirow{12}{*}{ 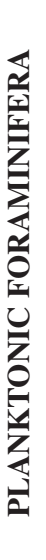 } & Globigerina aequilateralis & + & + \\
\hline & Lagena distoma & + & + & & Globgerina falcanensis & + & - \\
\hline & Lagena laevis & - & + & & Globigerina pachyderma & + & - \\
\hline & Lagena striata & + & + & & Globigerinita uvula & + & - \\
\hline & Lenticulina sp. & + & + & & Globigerinoides ruber & + & + \\
\hline & Marginulina spp. & + & + & & $\begin{array}{c}\text { Globigerinoides trilobus } \\
\text { (saculifera) }\end{array}$ & + & - \\
\hline & Nonionella atlantica & + & + & & Globorotalia sp. & + & - \\
\hline & Nonionella opima & + & - & & Globorotalia truncatulinoides & + & + \\
\hline & Oolina melo & + & + & & Globorotalia menardi & + & + \\
\hline & Oolina vilarboana & + & + & & Neogloboquadrina duteitrei & + & - \\
\hline & Oolina universa & + & + & & Neogloboquadrina sp. & + & - \\
\hline & Orthomorphina filiformis & + & + & & Pulleatina obliquiloculata & + & - \\
\hline
\end{tabular}

Table 4. The most frequent species found during the two seasonal periods of the study. The bold names are those species with frequencies higher than 5\% in winter and summer.

\begin{tabular}{rllc}
\hline $\boldsymbol{( \% )}$ & \multicolumn{1}{c}{ Winter/2003 } & \multicolumn{1}{c}{ Summer/2004 } & $(\boldsymbol{\%})$ \\
\hline $\mathbf{3 7 . 3 3}$ & Globocassidulina subglobosa & Globocassidulina subglobosa & $\mathbf{1 7 . 9 0}$ \\
$\mathbf{7 . 7 5}$ & Uvigerina peregrina & Bulimina marginata & $\mathbf{1 4 . 8 5}$ \\
$\mathbf{7 . 0 8}$ & Bulimina marginata & Uvigerina peregrina & $\mathbf{1 0 . 9 8}$ \\
$\mathbf{6 . 0 7}$ & Buccella peruviana & Buccella peruviana & $\mathbf{7 . 3 4}$ \\
4.70 & Nonionella atlantica & Bolivina striatula & $\mathbf{7 . 2 2}$ \\
4.61 & Hanzawaia boueana & Hanzawaia boueana & $\mathbf{6 . 9 5}$ \\
4.20 & Bolivina striatula & Nonionella atlantica & $\mathbf{5 . 8 3}$ \\
2.42 & Robulus sp. & Elphidium poeyanum & 3.42 \\
1.58 & Ammonia rolshauseni & Buliminella elegantissima & 2.93 \\
1.39 & Cibicides refulgens & Globigerinoides ruber & 1.89 \\
1.28 & Textularia earlandi & Ammonia rolshauseni & 1.46 \\
1.22 & Buliminella elegantissima & Lagena striata & 1.15 \\
1.20 & Globocassidulina crassa porrecta & Robulus sp. & 1.13 \\
1.14 & Anglogerina angulosa & Globorotalia menardi & 1.01 \\
1.07 & Elphidium poeyanum & Cibicides mackannai & 1.01 \\
1.01 & Arenoparella mexicana & & \\
1.01 & Ammonia beccarii & &
\end{tabular}

the north of Rio Grande $\left(31.5^{\circ} \mathrm{S}\right)$ in areas deeper than $20 \mathrm{~m}$. In Torres, in the winter, in the shallowest station, the absence of this species indicates low accumulation of coastal water in this site. In the summer, similar patterns were observed, with some peaks of occurrence more to the south in the deepest stations of Punta del Este and Punta Medanos indicating penetration of warm currents down south in deeper parts.

Uvigerina peregrina presents significant occurrence in the north part of the study area. In the winter, it presents peak in Albardão (59.5\%), at $53 \mathrm{~m}$ of depth, and the southern limit of its occurrence is in Punta del Este, at more than $64 \mathrm{~m}$ deep. In the summer, the occurrence pattern is similar being compared with the Globocassidulina subglobosa. It is observed, however, an increase of Uvigerina peregrina in the summer mainly in the Santa Marta Cape, probably indicating the presence of the SACW, since this species is known to be characteristic of regions of high productivity in upwelling zones. G. subglobosa and Uvigerina peregrina present peaks of occurrence (56.4\%, and $47.6 \%$, respectively) in the summer in Mar del Plata and P. Medanos in the deepest stations, suggesting reach of the STSW in this transect. Hanzawaia boueana in the winter presents peaks (17.9\%) in the shallowest warmer stations, and in the summer, the peak of occurrence is in Rio Grande $(26.7 \%)$.

The Figure $4 \mathrm{c}$ presents the distribution of Bulimina marginata, a characteristic species of the Subtropical Shelf Front (STSF), and Buccella peruviana, 

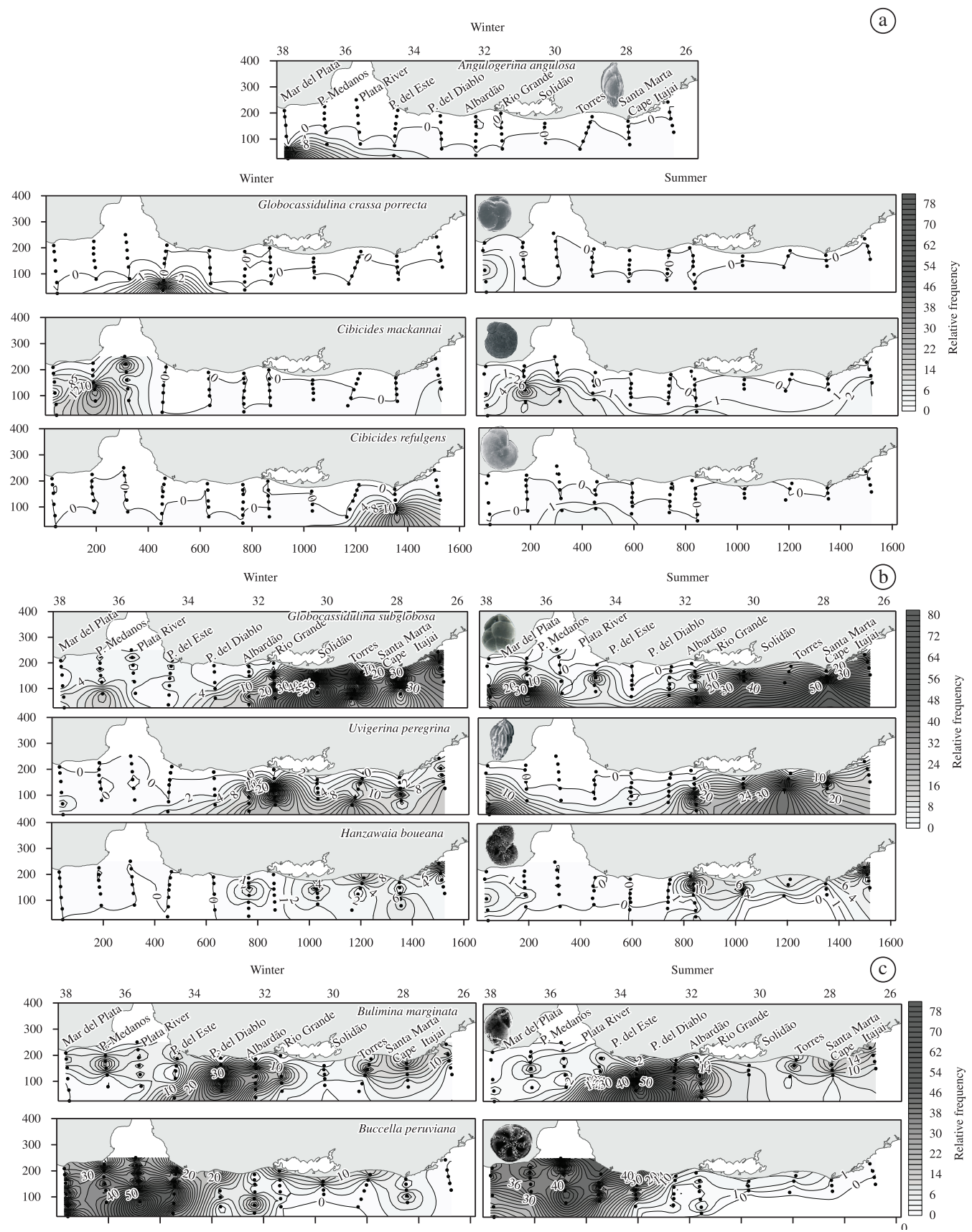

Figure 4. a) Slope water species; b) Subtropical Shelf Water (STSW), South Atlantic Central Water (SACW) and Tropical Water (TW) species; c) Subtropical Shelf Front (STSF) species and SubAntarctic shelf water (SASW) species.

a characteristic species of the Subantarctic Shelf water (SASW). Bulimina marginata in both seasons occurs between Punta del Este and Rio Grande, and it is indicative of the region of little variability of the STSF, with peak in Punta del Diablo, at $41 \mathrm{~m}$ deep in the winter and $60 \mathrm{~m}$ deep in the summer. Buccella peruviana is mainly dominant in the south of Punta del Diablo in the winter and the summer. It is observed, however, in the winter that its distribution occurs next to the coast in practically all the transects, but in Santa Marta its occurrence is verified in the deepest layers (105 and $130 \mathrm{~m}$ deep).

Figure 5 presents Ammobaculites exiguus, Arenoparrella mexicana, Gaudryina exillis, Textularia earlandi, and thecamoebian (truly freshwater organisms) as characteristic of the freshwater of the estuary of the Plata River and Patos Lagoon. Ammobaculites exiguus presents peaks $(10.2 \%)$ in the winter in Punta del Este in $65 \mathrm{~m}$ deep. In the summer, the peak $(10.6 \%)$ appears 

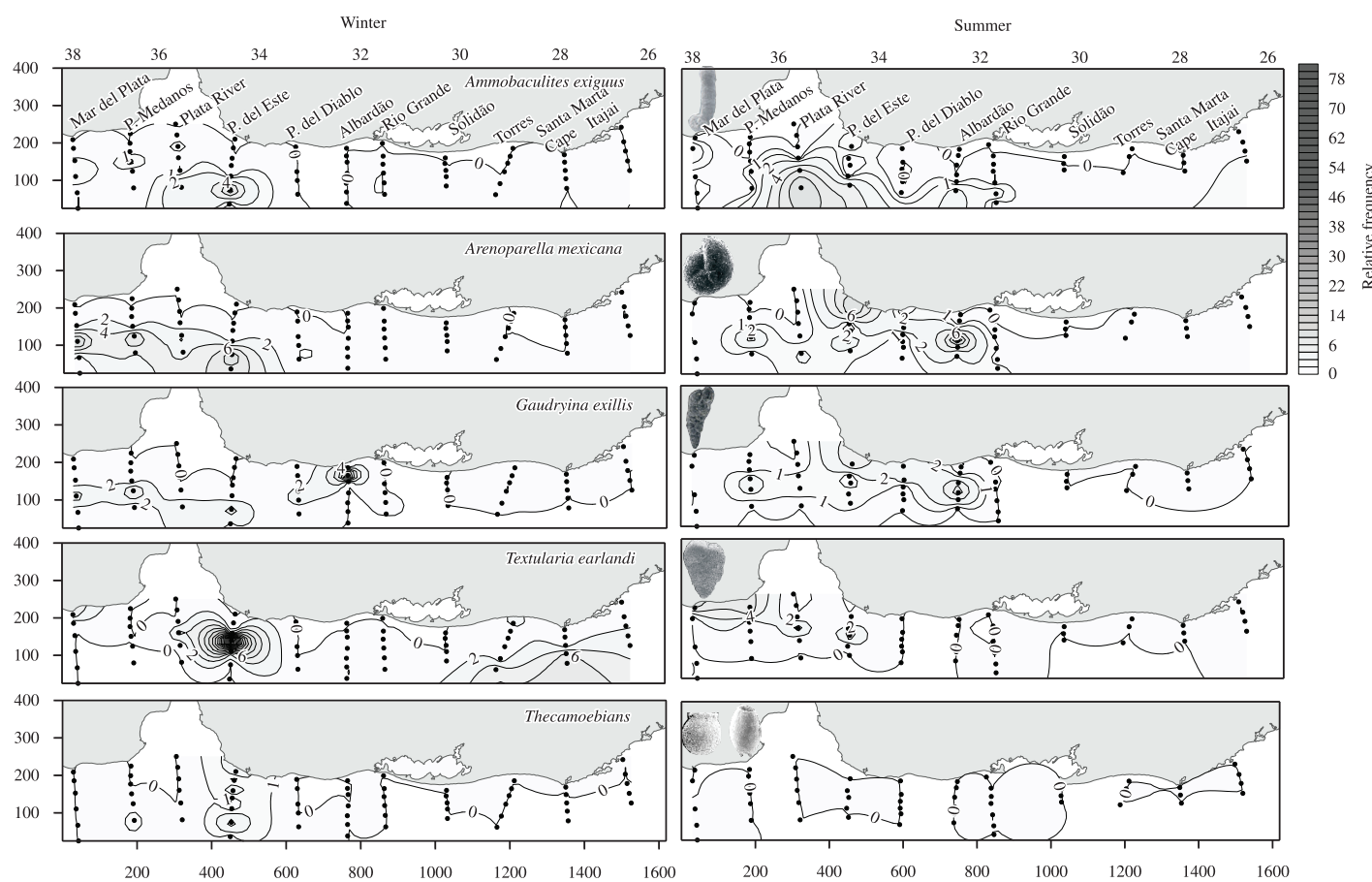

Figure 5. Estuarine water species of Plata River and Patos Lagoon.

in the deepest region in front of the estuary of the Plata River (95 m). Arenoparrella mexicana presents peak of occurrence $(12 \%, 9.4 \%$ and $10.2 \%)$ between 64 and $87 \mathrm{~m}$ in the transects of Mar del Plata, Punta Medanos and Punta del Este. In the summer, the occurrence peak (11.1\% and 14.6\%) for this species is in Albardão (92 m) and in Punta del Este $(40 \mathrm{~m})$. Gaudryina exilis presents peaks of abundance $(7.8 \%)$ in the winter in the Albardão (37 $\mathrm{m})$, and in the summer, peaks of occurrence $(6.3 \%)$ are in Punta Medanos $(80 \mathrm{~m})$, Punta del Este $(28 \mathrm{~m})$ and Albardão (64 m). Textularia earlandi presents peak of occurrence $(50 \%)$ in the winter in Punta del Este $(22 \mathrm{~m})$, and in the summer (7.1\%) in Punta Medanos (23 m). The thecamoebians tests have been observed mainly in the winter at depths of $64 \mathrm{~m}$, in Punta del Este. The influence of the fluvial discharge is observed at a depth of $92 \mathrm{~m}$ in the region of the Albardão, indicating that the influence of freshwater water discharge of the Patos Lagoon in the platform is more intense in the summer.

Regional relative abundances of the main dominant species follow clear latitudinal gradients, and the dominant Foraminiferal associations indicate different bottom environments. In both seasons more than $30 \%$ of Buccella peruviana indicates the presence of cold Subantarctic Shelf Water (SASW), mainly in the southern sector, from 33.5 to $38.3^{\circ} \mathrm{S}$ in the south of Punta del Este (Transect 4). In summer, however, at stations deeper than $100 \mathrm{~m}$, the abundance of this association decreases to less than $15 \%$ around $37.5-38.9^{\circ} \mathrm{S}$ closer to Mar del Plata (Transect 1) where two species (Globocassidulina subglobosa, Uvigerina peregrina) take over.
The association containing Globocassidulina subglobosa, Uvigerina peregrina, and Hanzawaia boueana, is mainly found at less than $55 \mathrm{~m}$ deep in both seasons, in the northern part of the area $\left(27-33^{\circ} \mathrm{S}\right)$, north of Punta del Diablo (Transect 5), and is linked with Subtropical Shelf Water. In four areas of the shelf, continental freshwater influence is detected by the presence of Pseudononion atlanticum, Bolivina striatula, and Buliminella elegantissima.

The first signal, between 34 and $35.5^{\circ} \mathrm{S}$, is from the Plata River in winter. The second freshwater signal, from the Patos Lagoon, is observed between 32.9 and $33.2^{\circ} \mathrm{S}$ in Albardão, in the winter, but farther south in the summer $\left(33.5-34.5^{\circ} \mathrm{S}\right)$. The third freshwater signal is observed between $29^{\circ}$ and $29.8^{\circ} \mathrm{S}$, and marks the influence of the Laguna estuarine system. The northernmost fresh water influence is from the Itajaí-Açú River, recorded between 27.3 and $27.5^{\circ} \mathrm{S}$ in the winter, but extending southward (to $28.8^{\circ} \mathrm{S}$ ) in the summer.

Also, related to coastal environments, the peaks of occurrence of freshwater related species as Ammobaculites exigus, Arenoparrella mexicana, Gaudryina exilis, Textularia earlandi, and thecamoebians along the coast in both seasons are a biological indicator of the influence of the Plata and Patos plume influence all over the region. The presence of Bulimina marginata between 34.1 and $32.8^{\circ} \mathrm{S}$ in the winter and 34.2 and $32.7^{\circ} \mathrm{S}$ in the summer, between Punta del Diablo and Albardão (Transects 5, 6), indicates that the influence of the Subtropical Shelf Front on the sediment does not change seasonally being a stationary front. 
Although similar latitudinal diversity trends were observed in summer and winter (Table 2 and 4); summer presents higher diversity than winter. In both seasons, the southern part of $35^{\circ} \mathrm{S}$ (Plata River) presents lower diversity, indicating that regions under influence of SASW are less diverse. In contrast, in the north of $35^{\circ} \mathrm{S}$ regions under the STSW influence are more diverse. It is interesting to note the abrupt decrease in the diversity around $35^{\circ} \mathrm{S}$ in the summer. There is a clear evidence of the pattern differentiation. The alterations of diversity benthic trends are due to the highest influence of one or other oceanic or coastal water masses adjacent to the bottom ocean.

\subsection{Hidrographic parameters}

Hidrographic and hydrochemical data (depth, salinity, temperature, dissolved oxygen and nutrients) of the bottom water in the winter and the summer can be observed in Figure 6. In the winter, in practically all the region we have observed lower salinity closer to the coast, in the shallowest stations, being, probably, described as Continental Water under direct influence of the Plata River plume. In the summer, this pattern is observed as far as the northernmost limit of the Albardão. Towards the north it is observed increase of the salinity.

In the winter, the temperature shows the clear separation between north and south parts, being both limited for cold water in the north and warm water in the south in Rio Grande at $50 \mathrm{~m}$ deep. The shallowest stations in the south of Rio Grande present cold waters and the deepest stations of Punta del Diablo and Albardão present warmer temperatures. In the summer, the temperature presents higher values closer to the coast, and in Rio Grande, warmer temperature follows the deepest stations of this transect.

In the winter, the oxygen pattern also presents clear separation between oxygenated waters in the south close to Rio Grande and lower values of oxygen in the north part, mainly in the deepest regions. In the summer, this clear separation pattern is not evidenced, but it follows the temperature pattern for the current limits.

It was possible to delimit three water masses in the region, in the winter: Continental water $(\mathrm{CW})$, being well oxygenated, cold with lower salinity; Subantarctic Shelf Water (SASW), being also well oxygenated, cold with low salinity and high silicate; and Subtropical Shelf Water (STSW), being less oxygenated, warmer and more saline than the CW and the SASW (Figure 6a). The clear differentiation of water masses pattern observed in the winter is less apparent in the summer, but the presence of warmer, less saline and less oxygenated water, characteristic of the STSW was detected all over the region.

Distribution maps of the nutrients from bottom water includes suspension matter (SM), organic matter (OM), silicate $\left(\mathrm{SI}\left(\mathrm{OH}_{4}\right)\right)$, nitrite $\left(\mathrm{NO}_{2}^{-}\right)$and nitrate $\left(\mathrm{NO}_{3}^{-}\right)$and can be visualized in Figure $6 b$.

It is observed that the suspension matter (SM) in the winter presents maximum in the stations closer to the coast in Punta del Diablo (Transect 5), and in the deeper stations of Rio Grande and Solidão (Transects 7, 8); and in the summer, the maximum occurs in Punta del Este (Transect 4) in the deepest stations.

The organic matter distribution follows the same pattern of suspension matter in the winter; and in the summer, the maximum also occurs in Punta del Este, and, in the more coastal stations is indicative of freshwater discharge with high concentration of organic matter. Silicate, associated to the presence of freshwater, presents high values in Punta Medanos, Punta del Este, Albardão, Torres and Santa Marta Cape (Transects 2, 4, 6, 9, 10) in the winter; and in the summer, the maximum occurs in Albardão and P. del Este (Transects 4, 6).

In the winter, nitrite presents maximum values in $\mathrm{P}$. Medanos, Mar del Plata, and Albardão (Transects 1, 2, 6) and in the summer, Punta del Diablo and Santa Marta (Transect 5, 10) present higher values. In the winter, peaks of occurrence of nitrate occur mainly in Mar del Plata and Punta del Este (Transects 2,4) in the deepest stations, and in the summer, increase in nitrate is observed mainly in the deepest stations of Punta Medanos and Plata River $(2,3)$. Nitrite and nitrate are nutrients that indicate presence of differentiated water masses. The presence of these peaks is probably related to SASW or SACW water masses, because these nitrate peaks can be related to the upwelling events. It is worthy to point out that in the summer we do not have nutrients data for bottom water in Itajaí (Transect 11).

\section{Discussion}

The abiotic data show the presence of three different water masses in the region, mainly in the winter: Continental water $(\mathrm{CW})$, being well oxygenated, cold and presenting the lowest salinity and high silicate; Subantarctic Shelf water (SASW), being also well oxygenated, cold with low salinity; and Subtropical Shelf Water (STSW), being less oxygenated, warmer and more saline than the CW and the SASW. In the summer, although less clear, the differentiation of the three water masses still exists.

The seasonality and reach of these water masses are responsible for the environment formed in the sediment, that in turn, propitiates the establishment of benthic species of Foraminifera in 8 groups: Continental Water (CW) species, organisms of continental origin, estuaries and salt marshes, and species related to the plume of the Plata River and the Patos Lagoon, and other estuarine systems like Laguna and Itajaí-Açu as well (PPW), Subantarctic Shelf Water (SASW), Malvinas currents (MC), Subtropical Shelf Water (STSW), Tropical Water (TW), South Atlantic Central Water (SACW) and Subtropical Shelf Front (STSF). Table 5 presents an attempt to summarize the benthic Foraminiferal species indicator, and the environmental parameters (temperature, salinity, oxygen, silicate, nitrite, and nitrate) characteristic of the different water masses. Although the planktonic Foraminifera deposited in the bottom also show differentiation between subantarctic, transitional and subtropical environments and have given information about the reach and limit of occurrence of the water masses, they were not described in the tables presented. 
Table 5. Foraminifera indicator species and environmental parameters (temperature, salinity, oxygen, silicate $\left(\mathrm{SiO}_{4}^{-}\right)$, nitrite $\left(\mathrm{NO}_{2}^{-}\right)$and nitrate $\left(\mathrm{NO}_{3}^{-}\right)$) in different water masses.

\begin{tabular}{|c|c|c|c|c|c|c|c|}
\hline Water masses & $\begin{array}{l}\text { Indicator } \\
\text { species }\end{array}$ & $\begin{array}{c}\text { Temperature } \\
\left({ }^{\circ} \mathbf{C}\right)\end{array}$ & $\begin{array}{l}\text { Salinity } \\
\text { (PSU) }\end{array}$ & $\begin{array}{l}\text { Oxygen } \\
\left(\mathrm{mLL}^{-1}\right)\end{array}$ & $\begin{array}{c}\text { Silicate } \\
\left(\mathrm{SiO}_{4}^{-}\right) \\
(\mu \mathrm{M}) \\
\end{array}$ & $\begin{array}{c}\text { Nitrite } \\
\left(\mathrm{NO}_{2}^{-}\right) \\
(\mu \mathrm{M}) \\
\end{array}$ & $\begin{array}{c}\text { Nitrate } \\
\left(\mathrm{NO}_{3}^{-}\right) \\
(\mu \mathrm{M}) \\
\end{array}$ \\
\hline \multirow{6}{*}{$\begin{array}{l}\text { Continental water } \\
(\mathrm{CW})\end{array}$} & B. striatula & Winter $<16$ & $<32.5$ & $>5.4$ & $>10$ & & \\
\hline & B. elegantissima & & & & & & \\
\hline & B. elongata & & & & & & \\
\hline & E. excavatum & Summer $<18$ & & & & & \\
\hline & E. poeyanum & & & & & & \\
\hline & N. atlantica & & & & & & \\
\hline \multirow{5}{*}{$\begin{array}{l}\text { Plata river plume } \\
\text { and patos lagoon* } \\
(\mathrm{PPW})\end{array}$} & A. exiguus & Winter 11-16 & $<34.0$ & Winter $<5.2$ & $>10$ & & \\
\hline & A. mexicana & & & & & & \\
\hline & G. exillis & & & & & & \\
\hline & T. earlandi & Summer $>13$ & & Summer $<4.6$ & & & \\
\hline & Thecamoebians & & & & & & \\
\hline \multirow{4}{*}{$\begin{array}{l}\text { Subantarctic shelf } \\
\text { water and slope } \\
\text { (SASW) }\end{array}$} & B. peruviana & Winter $<15$ & $33.7-34.0$ & $<5.4$ & $<10$ & & \\
\hline & $\begin{array}{l}\text { G. crassa } \\
\text { porrecta }\end{array}$ & & & & & & \\
\hline & C. mackannai & Summer $<12$ & & & & & \\
\hline & C. refulgens & & & & & & \\
\hline $\begin{array}{l}\text { Malvinas currents } \\
\text { (MC) }\end{array}$ & A. angulosa & Winter $<8$ & $33.5-34.5$ & $<5.4$ & $<10$ & $0.5-1.0$ & $5-10$ \\
\hline Subtropical shelf & G. subglobosa & & & & & & \\
\hline $\begin{array}{l}\text { water } \\
(\text { STSW) }\end{array}$ & $U$. peregrina & $>12$ & $>34.5$ & $>5.0$ & $<10$ & & \\
\hline $\begin{array}{l}\text { Tropical water } \\
\text { (TW) }\end{array}$ & H. boueana & $>20$ & $>36.4$ & $>5.4$ & $<10$ & & \\
\hline $\begin{array}{l}\text { South atlantic } \\
\text { central water } \\
(\mathrm{SACW})\end{array}$ & $U \cdot$ peregrina & $<20$ & $<36.4$ & $<4.2$ & $<10$ & & \\
\hline $\begin{array}{l}\text { Subtropical shelf } \\
\text { front } \\
\text { (STSF) }\end{array}$ & B. marginata & $\begin{array}{c}\text { Winter 11-16 } \\
\text { Summer 13-21 }\end{array}$ & $<34.5$ & $\begin{array}{l}\text { Winter 5.4-6.4 } \\
\text { Summer }<4.6\end{array}$ & $>3.5$ & $0.25-0.7$ & $1.0-2.0$ \\
\hline
\end{tabular}

*Origin: continental, estuaries and mangroves.

The Continental Water (CW) is an oceanic saline water combination with deriving freshwater from continental discharge found as far as the depth of $50 \mathrm{~m}$ presents Bolivina striatula, Buliminella elegantissima, Bulimina elongata, Elphidium excavatum, Elphidium poeyanum, and Nonionella atlantica as dominant species.

The areas of higher incidence of this water mass are mainly the Albardão $\left(32^{\circ} \mathrm{S}\right)$, in the winter; and the Plata River $\left(35.8^{\circ} \mathrm{S}\right)$, in the summer. There is also an evidence of presence of $\mathrm{CW}$ mainly in the region of the Albardão during the two campaigns. Boltovskoy et al. (1980), describe Bolivina striatula, Buliminella elegantissima, Elphidium excavatum, E. gunteri, and Elphidium spp. as being marine euryhaline, tolerant to less saline waters of the Patos Lagoon and Plata River, and Eichler et al. (2007) have found Buliminella elegantissima, Elphidium excavatum, and Elphidium poeyanum in polyhaline water (18-30 psu) where sand-silt sediments of Bertioga estuarine channel are enriched with organic carbon and sulfur. In the present platform study, they also occur in places that suggest diluted oceanic water reach.

In the Subtropical Shelf Water (STSW) (where $\mathrm{T}>12{ }^{\circ} \mathrm{C}$ and $\left.\mathrm{S}>34.5\right)$ the main species are Globocassidulina subglobosa, Uvigerina peregrina, and Hanzawaia boueana (TW) that occur mainly to the north of Rio Grande $\left(31.5^{\circ} \mathrm{S}\right)$ in areas deeper than $20 \mathrm{~m}$. Two of this species (Globocassidulina subglobosa and Uvigerina peregrina) also have been described by Boltovskoy et al. (1980) as species carried by the Brazil Current. Our findings show that peaks of occurrence of these species are found to the north of the study area. In the summer, higher incidence of this water mass is observed in the south. In the winter, the south limit of the STSW seems to be the shallowest stations of Torres $\left(28.5^{\circ} \mathrm{S}\right)$, and in the summer, Globocassidulina subglobosa and 

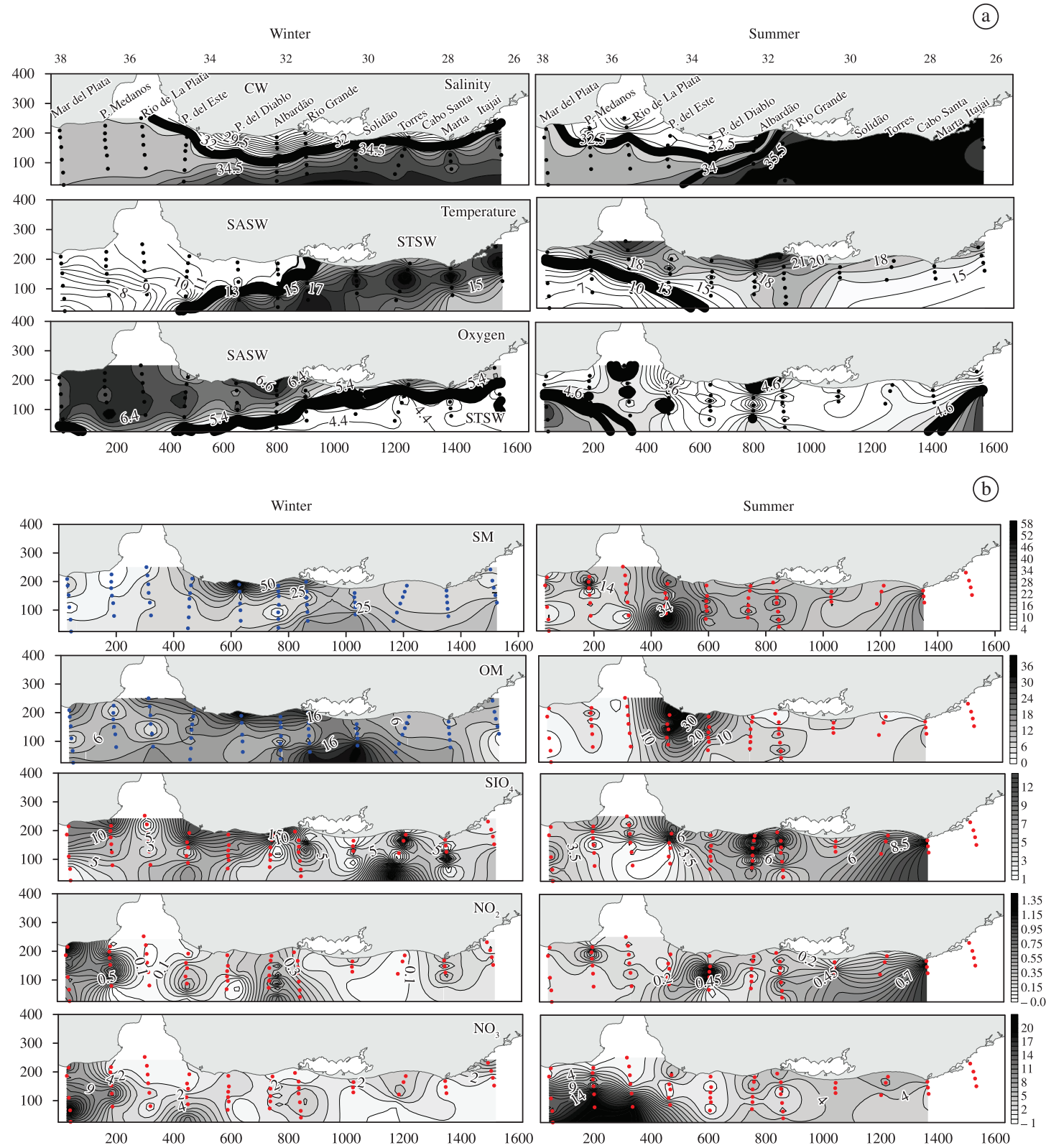

Figure 6. a) Three different water masses in the bottom. b) distribution of suspension matter (SM), organic matter (OM), silicate $\left(\mathrm{SiO}_{4}^{-}\right)$, nitrite $\left(\mathrm{NO}_{2}^{-}\right)$and nitrate $\left(\mathrm{NO}_{3}^{-}\right)$.

Uvigerina peregrina present peaks of occurrence in deepest stations of Mar del Plata $\left(38^{\circ} \mathrm{S}\right)$, suggesting reach of the STSW as south as this transect. As Uvigerina peregrina is also an indicative species of high primary productivity (Mulitza et al., 2004; Schmiedl et al., 2004) we can correlate its occurrence in the present study with the presence of the SACW at least in the summer in the northern part of the study area.

Bulimina marginata occurring between Punta del Este $\left(34.8^{\circ} \mathrm{S}\right)$ and Rio Grande $\left(31.5^{\circ} \mathrm{S}\right)$, with peak of occurrence in Punta Del Diablo $\left(33^{\circ} \mathrm{S}\right)$ in $41 \mathrm{~m}$ deep is the only characteristic species of the Subtropical Shelf Front, capable of adapting to the high variability dynamics in the transitional area where two coastal water masses (STSW and SASW) meet, and also still receives great seasonally influence from the Patos Lagoon and the Plata River.

The slope species Globocassidulina crassa porrecta, Cibicides mackannai, Cibicides refulgens, and Angulogerina angulosa found in the deepest stations to the south of the study area can be correlated to cold waters in agreement with the literature where the proximity of the Malvinas currents is verified by the presence of Angulogerina angulosa, cold water species, related to the glacial age (Khusid et al., 2005), and to the Antarctic Circumpolar Water and Antarctic Surface Water (Uchio, 1960). Angulogerina angulosa is the dominant in this 
current and in accordance with Boltovskoy et al. (1980), Globocassidulina crassa porrecta, is characteristic of the Falklands Islands and Tierra del Fuego.

In Callao, Peru, Buccella peruviana was described as being carried to the Atlantic via subantarctic waters (Boltovskoy, 1950) and our results showed that this species is characteristic species of the Subantarctic Shelf Water (SASW) $\left(\mathrm{T}<15^{\circ} \mathrm{C}\right.$ and $\left.33.7<\mathrm{S}<34.15\right)$ dominant mainly below Punta Del Diablo $\left(33^{\circ} \mathrm{S}\right)$ in the two cruises. Stevenson et al. (1998) describe this species as a temperate water species typical of Argentine Province and they concluded that the Subantartic waters have reached lagoonal areas situated in the northernmost part of Rio de Janeiro $\left(22^{\circ} \mathrm{S}\right)$.

The highest differentiation of the distributional patterns of Buccella peruviana in the summer occurs between Punta Del Diablo (33 $\left.{ }^{\circ} \mathrm{S}\right)$ and Albardão $\left(32^{\circ} \mathrm{S}\right)$. It is observed, however, that in the winter, its distribution occurs closer to the coast in practically all transects, but in Santa Marta $\left(28^{\circ} \mathrm{S}\right)$ it occurs in the deepest stations (105 and $\left.130 \mathrm{~m}\right)$. Despite of Moller et al. (2008) findings which suggest that SASW does not reach areas beyond $32^{\circ} \mathrm{S}$, the occurrence of $B$. peruviana in these deeper layers suggests that this species may have been transported to lower latitudes in the winter. Such phenomenon calls for further detailed studies (Eichler et al., 2008) because the presence of Buccella peruviana during the winter at Santa Marta Cape $\left(28^{\circ} \mathrm{S}\right)$ suggest that this species was passively transported by prevailing northward shelf currents.

In another approach, Eichler et al. (2012) studying Foraminifera as indicators of marine pollutant contamination on the inner continental shelf of southern Brazil inferred that the distribution of Buccela peruviana is being distributed mostly by temperature, depth, salinity, and percentage of sand other than percentage of clay and total coliforms.

The agglutinated species Ammobaculites exiguus, Arenoparrella mexicana, Gaudryina exillis, Textularia earlandi, and the thecamoebian tests, found in the coastal stations are carried by coastal currents, and although these species are characteristic species of mixohaline environments, being therefore, characteristics from both Plata River, Patos Lagoon, and Laguna system the denomination of the species was made on the basis of the highest freshwater influence that the Plata River exerts on the region. In the winter, the peak of these species occurs in Punta del Este $\left(34.8^{\circ} \mathrm{S}\right)$ at $65 \mathrm{~m}$ of depth. In the summer, the peak appears in the deepest region of the Plata River $\left(35.8^{\circ} \mathrm{S}\right)$, being indicative of influence of freshwater discharge as deep as $95 \mathrm{~m}$.

Until the present moment, the description of the peaks of occurrence of the species was based on the spatial distribution and diversity and it was possible to seasonally and latitudinally differentiate the main influencing water masses in the study region. The correlation of the environment and the Foraminifera species through multivariate analyses is still intended, to reveal the main current productivity peaks.

The knowledge of the current productivity peaks, circulation pattern of water masses, levels of marine nutrients and recent and taphonomic Foraminifera data (transport of the tests) together with further isotopic analysis in the Foraminifera tests will provide information to study the changes in the sediment over the last years, due to water matter interactions, in selected sites with environmental importance on the continental platform.

\section{Conclusions}

The abiotic data were able to distinguish the presence of three different water masses in the region, mainly in the winter: Continental water (CW), being well oxygenated, cold and presenting the lowest salinity and high silicate; Subantarctic Shelf water (SASW), being also well oxygenated, cold with low salinity and high nutrients; and Subtropical Shelf Water (STSW), being less oxygenated, warmer and more saline than the CW and the SASW. In the summer, although less clear and deviated southward, the differentiation of the three water masses still exists.

The biological data showed the establishment of benthic species of Foraminifera in 8 groups, in accordance with the latitude, seasonality, and reach of the three water masses: Continental Water (CW) species, organisms of continental origin, estuaries and salt marshes, and species related to the plume of the Plata River and Patos Lagoon (Laguna estuarine system and Itajaí-Açu River) (PPW), Subantarctic Shelf Water (SASW), Malvinas currents (MC), Subtropical Shelf Water (STSW), Tropical Water (TW), South Atlantic Central Water (SACW) and Subtropical Shelf Front (STSF).

The latitudinal diversity of Foraminiferal species can be extrapolated to understand climate change over decadal time in down core studies by looking at the penetration of warm currents towards the south. If the ocean water is warming, the penetration south ward of warmer currents will have increased over the last few years, and this can be observed by the increase in the Foraminifera diversity pattern towards the south.

Acknowledgements - The first author thanks the Brazilian National Council of Research (CNPq/PDE OC 200424/2005) for a postdoctoral fellowship grant at the University of Delaware. The PLATA Cruises and some laboratory work were financially supported by the U.S. Office of Naval Research (ONR, Grant N00014-02-1-0295), the Inter-American Institute for Global Change Research (IAI, Grant SACC/CRN-061), and the Fundação de Amparo à Pesquisa do Estado de Sao Paulo (FAPESP, Grant 2004/01950-3). We are also grateful for the analytical contribution (Suspension matter, organic matter, silicate, nitrate and nitrite) from Elisabete de Santis Braga, Vitor Chiozzine and Glaucia Berbel from Oceanographic Institute of Sao Paulo, Brazil. We gratefully acknowledge the help of personnel from DHN (Brazil), SHN (Argentina), and SOHMA (Uruguay) in obtaining all necessary clearance. SeCIRM provided fuel for the Summer Cruise. Special thanks are due to the crew of the Argentinean oceanographic vessel Ara Puerto Deseado and the Brazilian oceanographic vessel Antares for their help with sample collection. Our last thanks goes to Dra. Helenice Vital and the funding agency Capes (Coordenação de aperfeiçoamento de Pessoal de nivel superior) through the Edital Ciências do Mar 207/2010 for the Post Doc Fellowship for the first author at Laboratório de Geologia e Geofísica Marinha e Monitoramento Ambiental da Universidade Federal 
do Rio Grande do Norte (GGEMMA-UFRN-Brazil) providing means for this research to be published.

\section{References}

BOLTOVSKOY, E., 1959. Foraminifera as biological indicator in study of ocean currents. Micropaleontology, vol. 5, no. 4, p. 473-481. http://dx.doi.org/10.2307/1484129

BOLTOVSKOY, E. and WRIGHT, R. 1976. Recent Foraminifera. The Hague: Junk. xvii+515 p., 133 figs, 17 tables.

BOLTOVSKOY, E., GIUSSANI, G., WATANABE, S. and WRIGHT, R., 1980. Atlas of benthic shelfforaminifera of Southwest Atlantic. The Hague: Junk. 147 p. http://dx.doi.org/10.1007/97894-009-9188-0

BRAGA, ES., CHIOZZINI, VG., BERBEL, GBB., MALUF, JCC., AGUIAR, VMC., CHARO, M., MOLINA, D., ROMERO, R. and EICHLER, BB., 2008. Nutrients distribution over the Southeastern South Atlantic continental shelf from Mar del Plata (Argentina) to Itajaí (Brazil): Winter-summer aspects. Continental Shelf Research, vol. 28, p. 1649-1661.

CAMPOS, EJD. and OLSON, DB., 1991. Stationary Rossby Waves In Western Boundary Current Extensions. Journal of Physical Oceanography, vol. 21, no. 8, p. 1202-1224. http:// dx.doi.org/10.1175/1520-0485(1991)021\%3C1202:SRWIWB $\% 3 \mathrm{E} 2.0 . \mathrm{CO} ; 2$

CAMPOS, EJD., LORENZZETTI, JA., STEVENSON, MR., STECH, JL. and DE SOUSA, RB., 1996. Penetration of Waters From The Brazil-Malvinas Confluence Region Along The South American Continental Shelf Up To 23 S. Anais da Academia Brasileira de Ciências, vol. 68, no. 1, p. 49-58.

CAMPOS, EJD., MUKHERJEEE, S., PIOLA, AR. and DE CARVALHO, FMS., 2008. A note on a mineralogical analysis of the sediments associated with the Plata River and Patos Lagoon outflows. Continental Shelf Research, vol. 28, p. 1687-1692, 2008. http://dx.doi.org/10.1016/j.csr.2008.03.014

CASTRO, BM. and MIRANDA, LB., 1998. Physical oceanography of the western Atlantic continental shelf located between 4N and 34S. In ROBINSON, AR. and BRINK, KH. (Ed.). The Sea. Hoboken: John Wiley. vol. 11, p. 209-251.

CLARKE, KR. and WARWICK, RM., 1994. Change in Marine Communities: an Approach to Statistical Analyses and Interpretation. Plymouth: Natural Environment Research Council. 144 p.

EICHLER, PPB., EICHLER, BB., MIRANDA, LB. and RODRIGUES, AR., 2007 Foraminiferal assemblages in a subtropical, mixohaline, estuarine channel, Bertioga (Sao Paulo) Brazil. Journal of Foraminiferal Research, vol. 37, no. 3, p. 45-58.

EICHLER, PPB., SEN GUPTA, BK, EICHLER, BB., BRAGA, ES. and CAMPOS, EJd., 2008. Benthic foraminiferal assemblages of the South Brazil: Relationship to water masses and nutrient distributions. Continental Shelf Research, vol. 28, p. 1674-1686. http://dx.doi.org/10.1016/j.csr.2007.10.012

EICHLER, PPB., EICHLER, BB., SEN GUPTA, BK. and RODRIGUES, AR., 2012. Foraminifera as indicators of marine pollutant contamination on the inner continental shelf of southern Brazil. Marine Pollution Bulletin, vol. 64, no. 1, p. 22-30. Pmid:22118897. http://dx.doi.org/10.1016/j.marpolbul.2011.10.032

ELLIS, BF. and MESSINA, AR., 1940. Catalogue of Foraminifera. New York Micropaleontology Project, Inc. Available from: <http:// www.micropress.org/e_m.html>.
GASTON, KJ. and BLACKBURN, TM., 2000. Pattern and processes in macroecology. Oxford: Blackwell Scientific.

GRASSHOFF, K., EHRHMARDT, M. and KREMLING, K., 1983. Methods of seawater analysis. 2nd. ed. Weinhein: Verlag Chimie. $419 \mathrm{p}$

HARLOFF, J. and MACKENSEN, A. 1997. Recent benthic foraminiferal associations and ecology of the Scotia Sea and Argentine Basin. Marine Micropaleontology, vol. 31, no. 1-2, p. 1-29. http://dx.doi.org/10.1016/S0377-8398(96)00059-X

HUSTON, MA., 1994. Biological diversity: the coexistence of species on changing landscapes. Cambridge: Cambridge University Press. 708 p.

KHUSID, TA., BARASH, MS., BIEBOW, N., NUERNBERG, D. and TIEDEMANN, R., 2005. Late Quaternary Environmental Changes on the Southeastern Slope of the Sea of Okhotsk Inferred from Benthic Foraminifera. Oceanology, vol. 45, no. 32005, p. 413-419.

MIRANDA, LB.,1972. Propriedades e variaveis físicas das águas da plataforma continental do Rio Grande do Sul.São Paulo: Universidade de são Paulo, Instituto de Física. 127 p. Tese de Doutorado.

MOLLER, O., PIOLA, AR., FREITAS, AC. and CAMPOS, EJD., 2008. The effects of river discharge and seasonal winds on the shelf off Southeastern South America. Continental Shelf Research, vol. 28, p. 1607-1624. http://dx.doi.org/10.1016/j. csr.2008.03.012

MULITZA, S., DONNER, B., FISCHER, G., PAUL A., PÄTZOLD, J. and SEGL, M., 2004. The South Atlantic oxygen-isotope record of planktic foraminifera: In Wefer, G., Mulitza, S. and Ratmeyer, V. (Eds.). The South Atlantic in the Late Quaternary: Reconstruction of Material Budgets and Current Systems. Heidelberg: SpringerVerlag. p. 121-142.

PIMENTA, FM., 2001. Estudo numérico da influência da descarga fluvial e dos ventos sobre a dinâmica da pluma do Rio da Prata. São Paulo: Universidade de São Paulo. 127 p. Dissertação de Mestrado em Oceanografia Física.

PIMENTA, FM., Campos, EJD., Miller, JL. and Piola, AR., 2005. A numerical study of the Plata River plume along the Southeastern South American continental shelf. Brazilian Journal of Oceanography, vol. 53. no. 3, p. 129-146

PIOLA, AR., CAMPOS, EJD., MOLLER, O., CHARO, M. and MARTINEZ, C., 2000. The Subtropical Shelf Front off eastern South America. Journal of Geophysical Research, vol. 105, p. 6565-6578. http://dx.doi.org/10.1029/1999JC000300

PIOLA, AR., MATANO, RP., PALMA, ED., MOLLER, O. and CAMPOS, EJD., 2005. The influence of the Plata River discharge on the western South Atlantic shelf. Geophysical Research Letters, vol. 32, L01603.

PIOLA, AR., MOLLER JUNIOR, OO., GUERRERO, R. and CAMPOS, EJD., 2008. Variability of the Subtropical Shelf Front off eastern South America: Winter 2003 and summer 2004. Continental Shelf Research, vol. 28, p. 1639-1647. http://dx.doi. org/10.1016/j.csr.2008.03.013

ROUGHGARDEN, J., 1986. A comparison of food-limited and space-limited animal competition communities. In Diamond, J. and Case, T. (Eds.). Community ecology. New York: Harper and Row. p. 492-516. 
SCHMIEDL, G., PFEILSTICKER, M., HEMLEBEN, C. and MACKENSEN, A., 2004. Environmental and biological effects on the stable isotope composition of recent deep-sea benthic foraminifera from the western Mediterranean Sea. Marine Micropaleontology, vol. 51, no. 1-2, p. 129-152. http://dx.doi. org/10.1016/j.marmicro.2003.10.001

SILVEIRA, ICA., SCHMIDT, ACK., CAMPOS, EJD., de GODOI, SS. and IKEDA, Y., 2000. The Brazil current off the Eastern Brazilian Coast. Brazilian Journal of Oceanography, vol. 48 , no. 2. p. 171-183.

STEVENSON, MR., DIAS-BRITO, D., STECH, JL. and KAMPEL, M., 1998. How do cold water biotas arrive in a tropical bay near
Rio de Janeiro, Brazil. Continental Shelf Research, vol. 18, no. 13, p. 1595-1612. http://dx.doi.org/10.1016/S0278-4343(98)00029-6

STRAMMA, L. and ENGLAND, M., 1999. On the water masses and mean circulation of the South Atlantic Ocean. Journal of Geophysical Research, vol. 104, no. C9, p. 20863-20883. http:// dx.doi.org/10.1029/1999JC900139

STRICKLAND, JDH. and PARSONS, TR., 1972. A Practical Handbook of Seaweater Analysis. 2nd ed. Ottawa: Fisheries Research Board of Canada. 310 p. Bulletin, no. 169.

UCHIO, T., 1960. Benthonic foraminifera of the Antarctic Ocean. Biological Results. Japanese Antarctic Research Expedition, vol. 12 , p. 3-20. 
Eichler, PPB. et al.

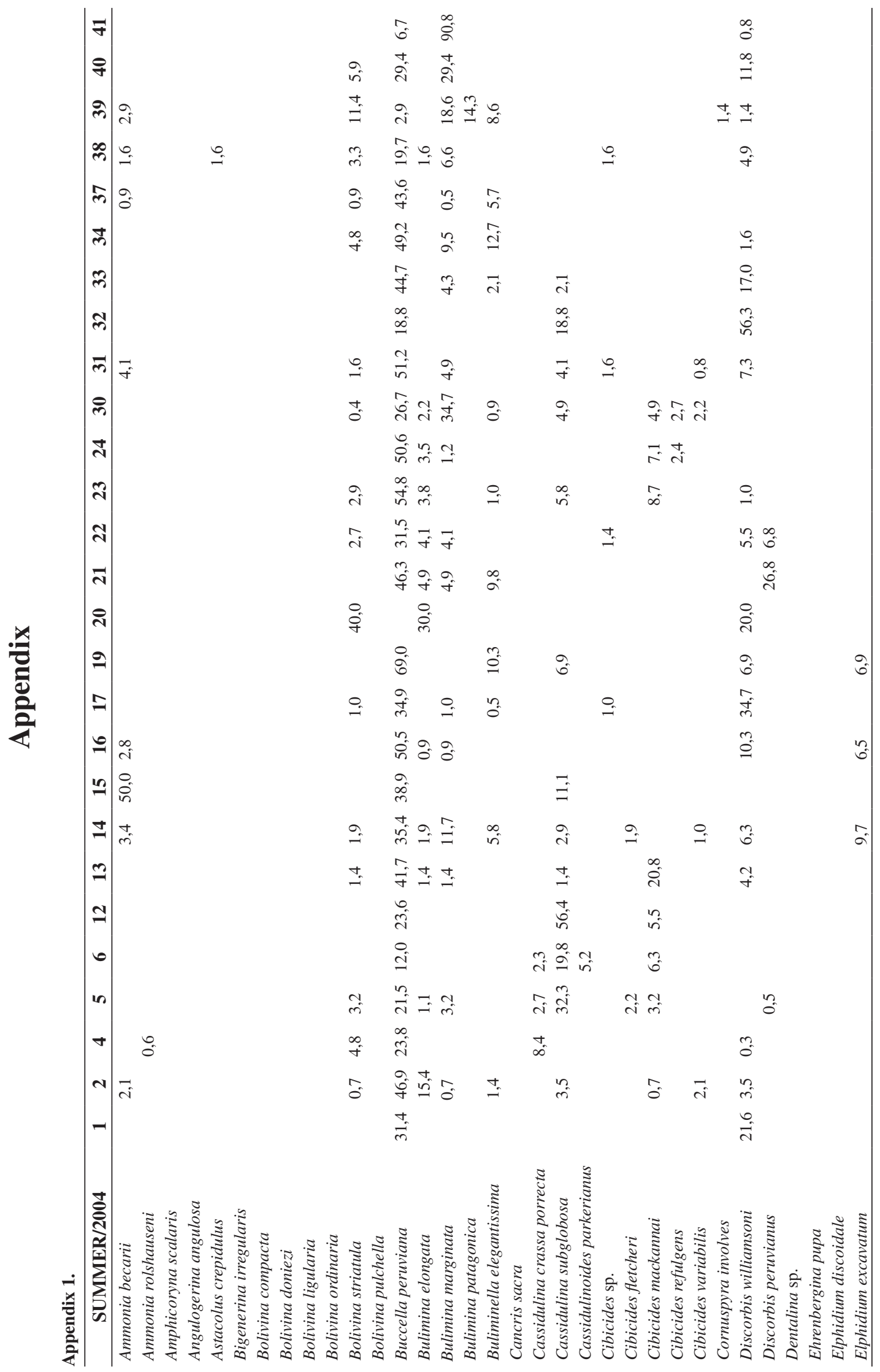


Tracing latitudinal gradient, river discharge and water masses

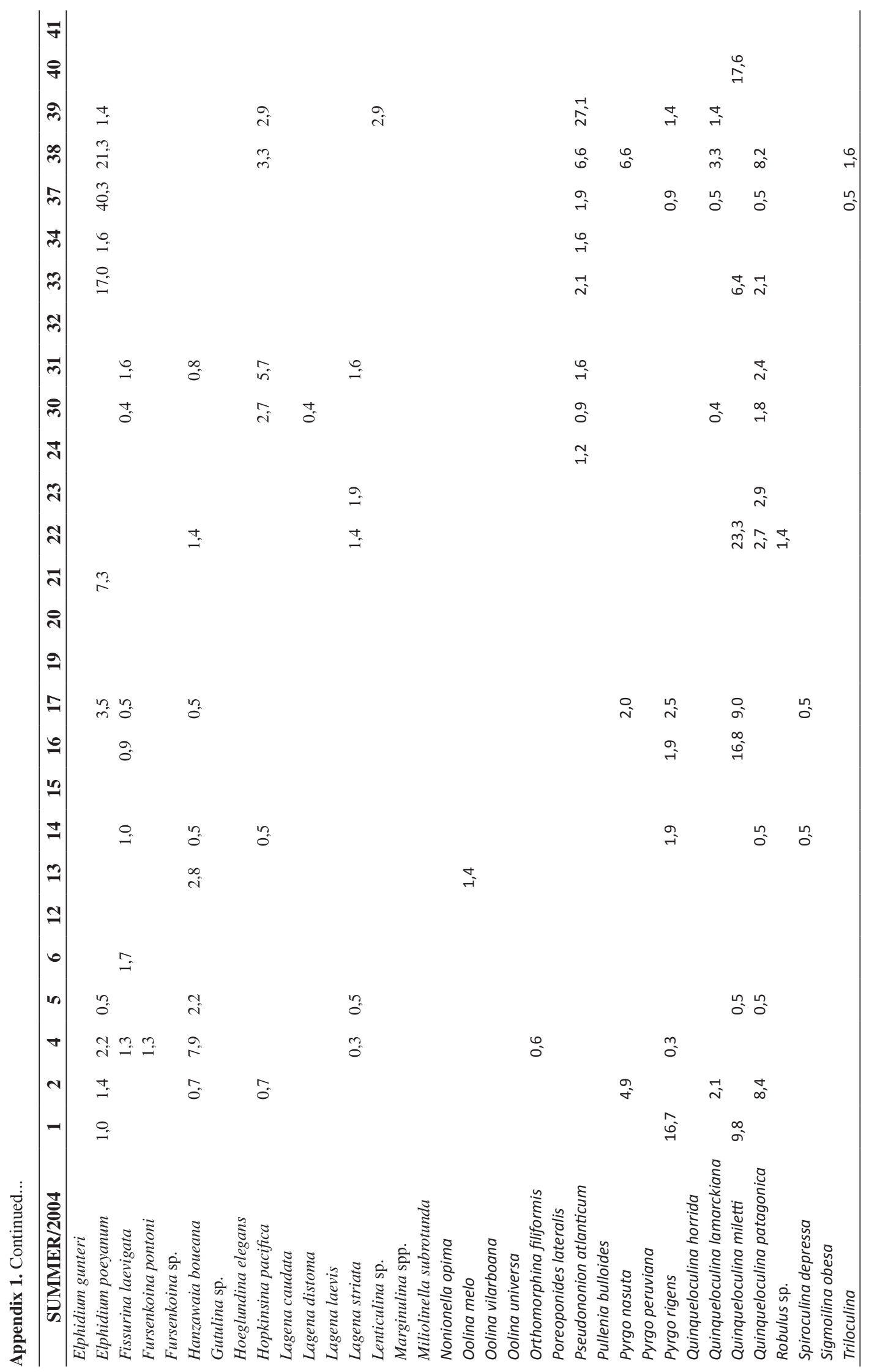


Eichler, PPB. et al.

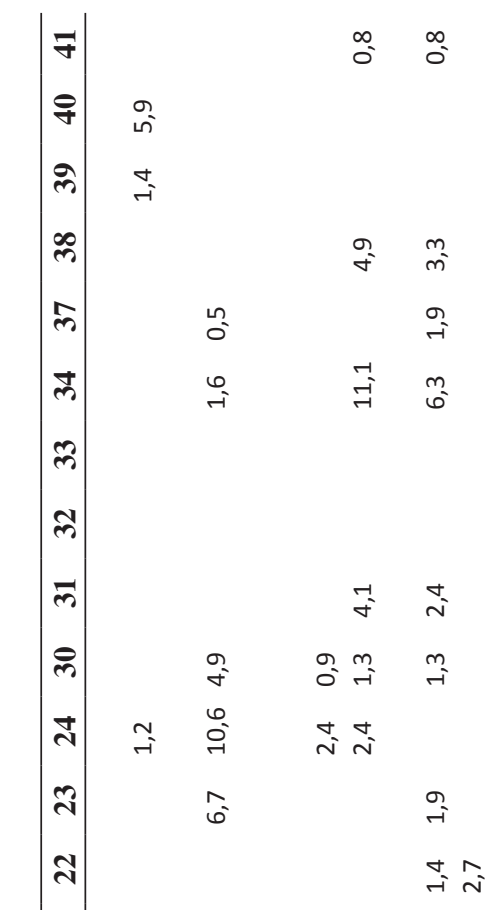

ฮุ

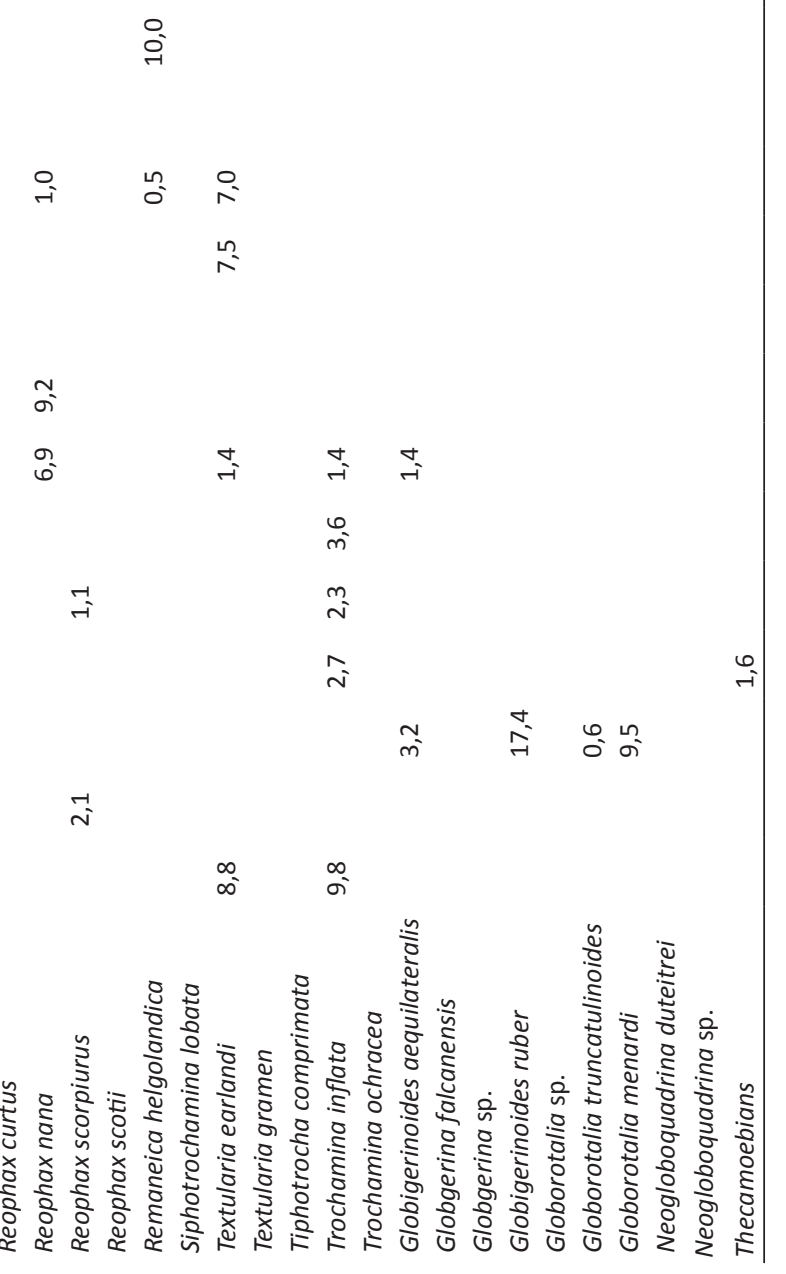

à

ก)

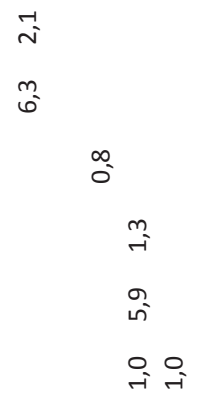

$\stackrel{+1}{*}$ เก

$\stackrel{-}{\circ}$

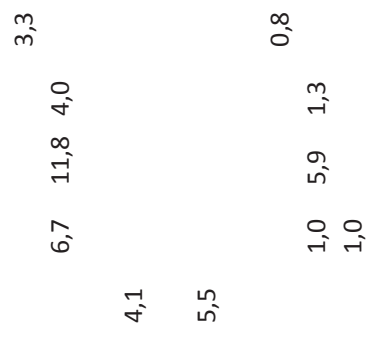

744

Braz. J. Biol., 2012, vol. 72, no. 3 (suppl.), p. 723-759 


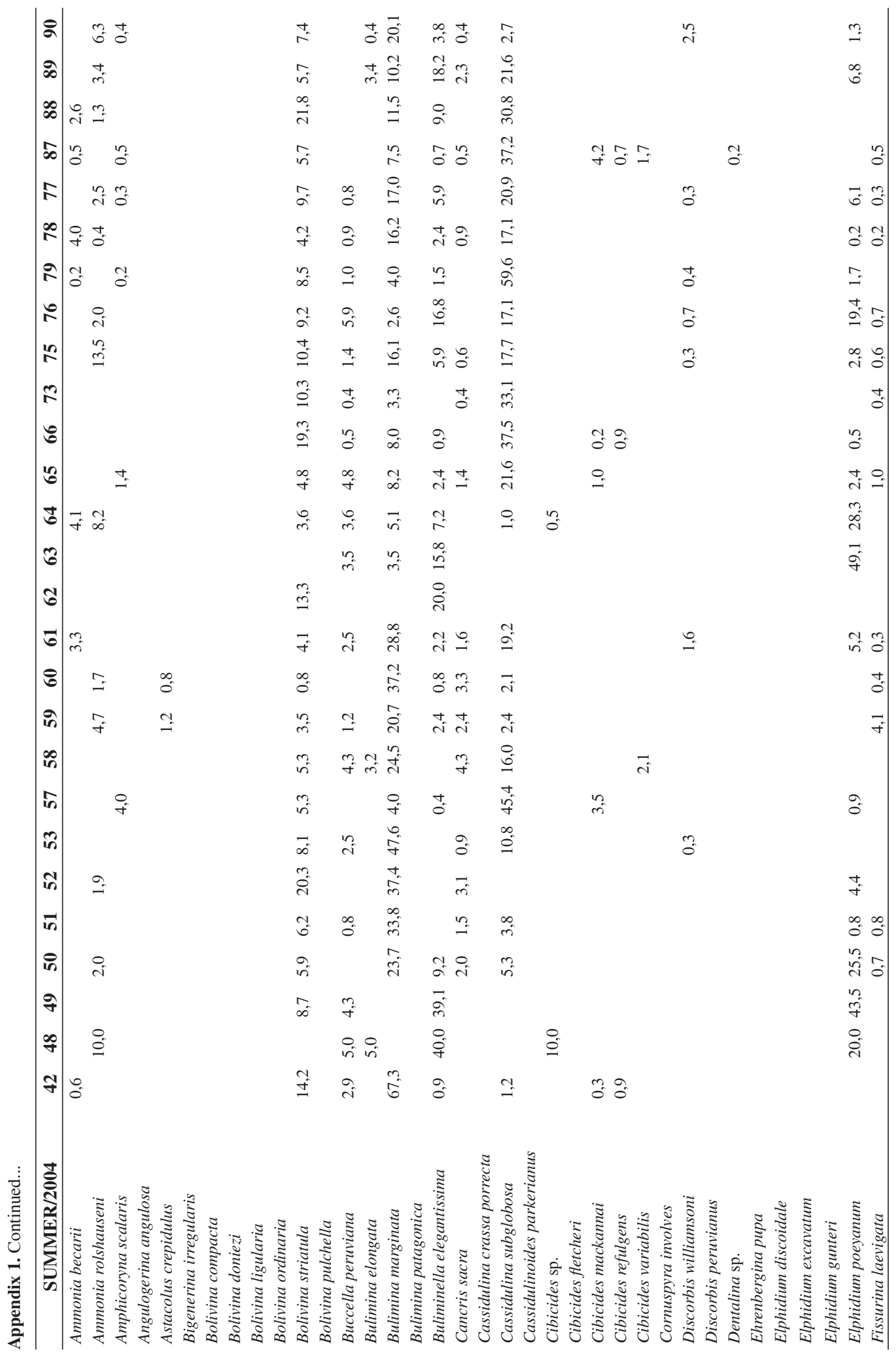


Eichler, PPB. et al.

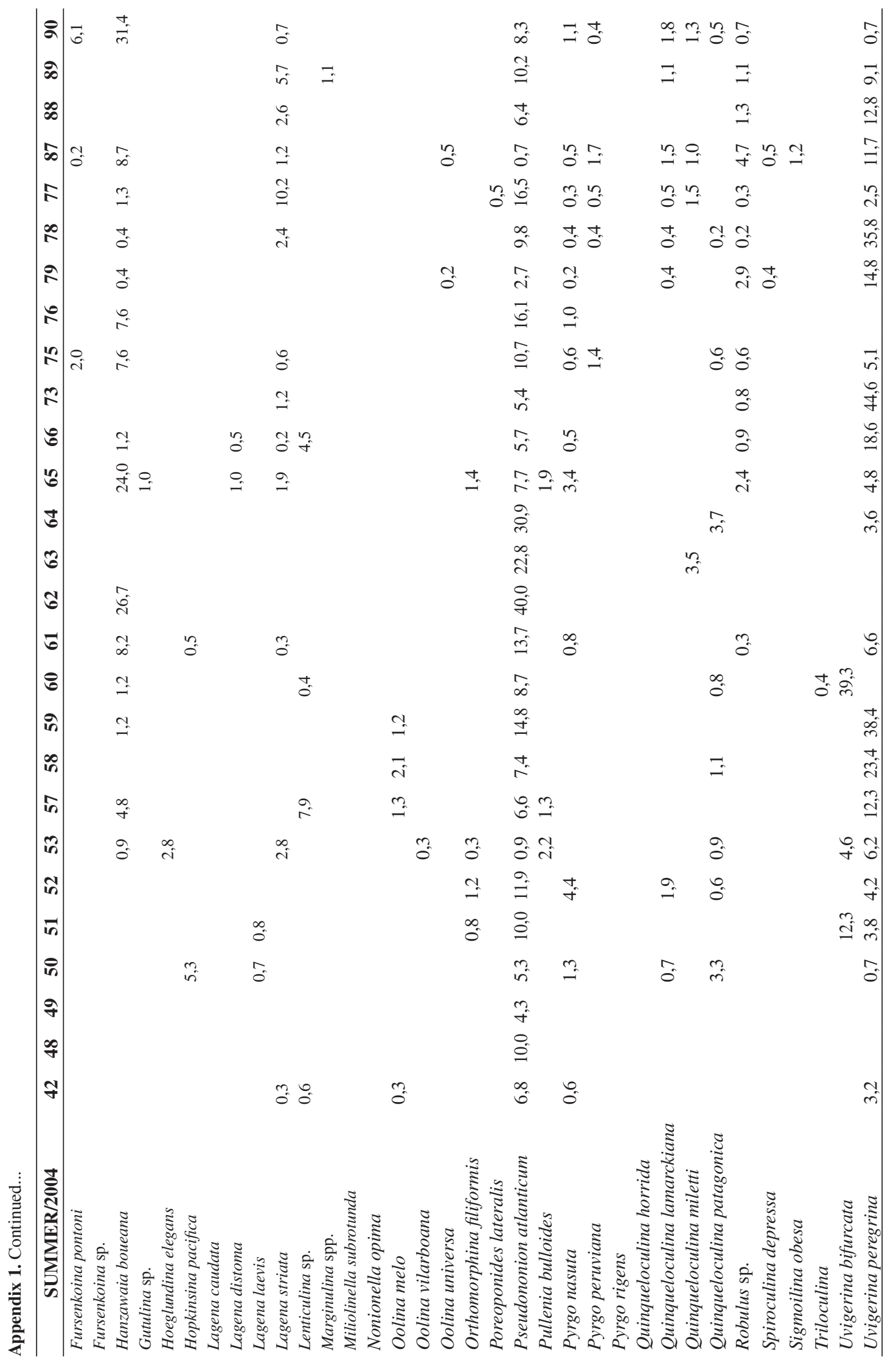




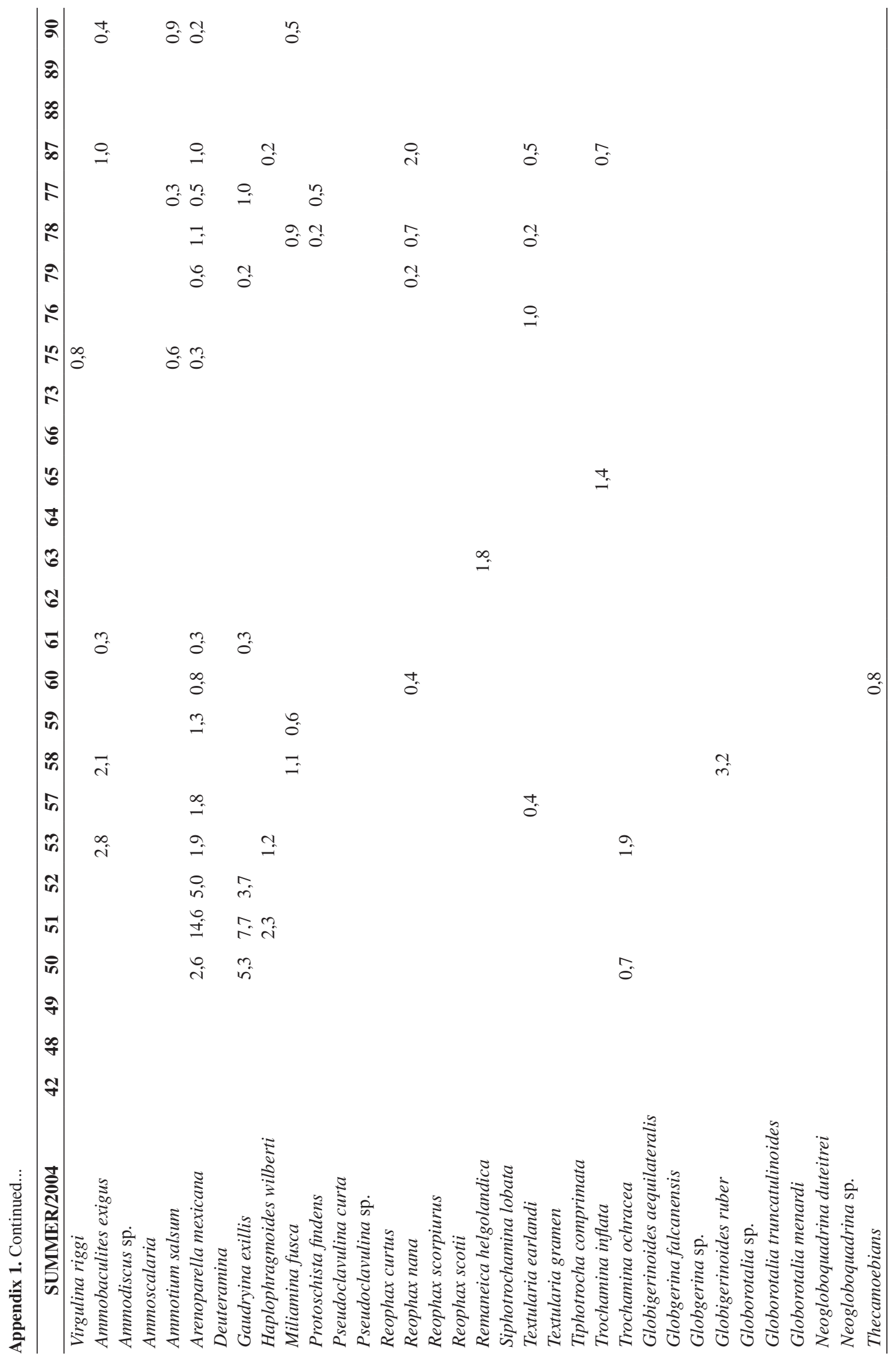


Eichler, PPB. et al.

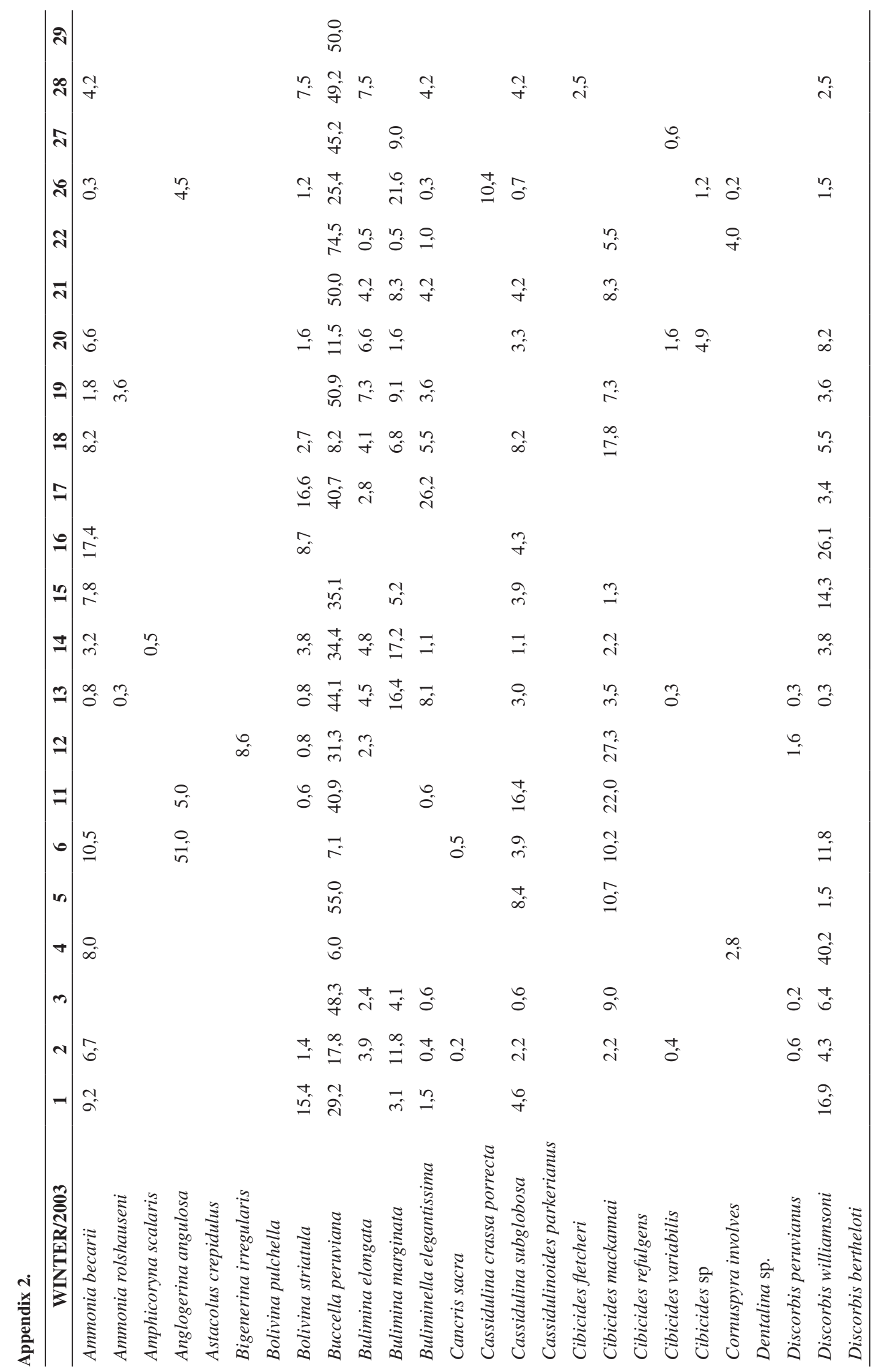


Tracing latitudinal gradient, river discharge and water masses

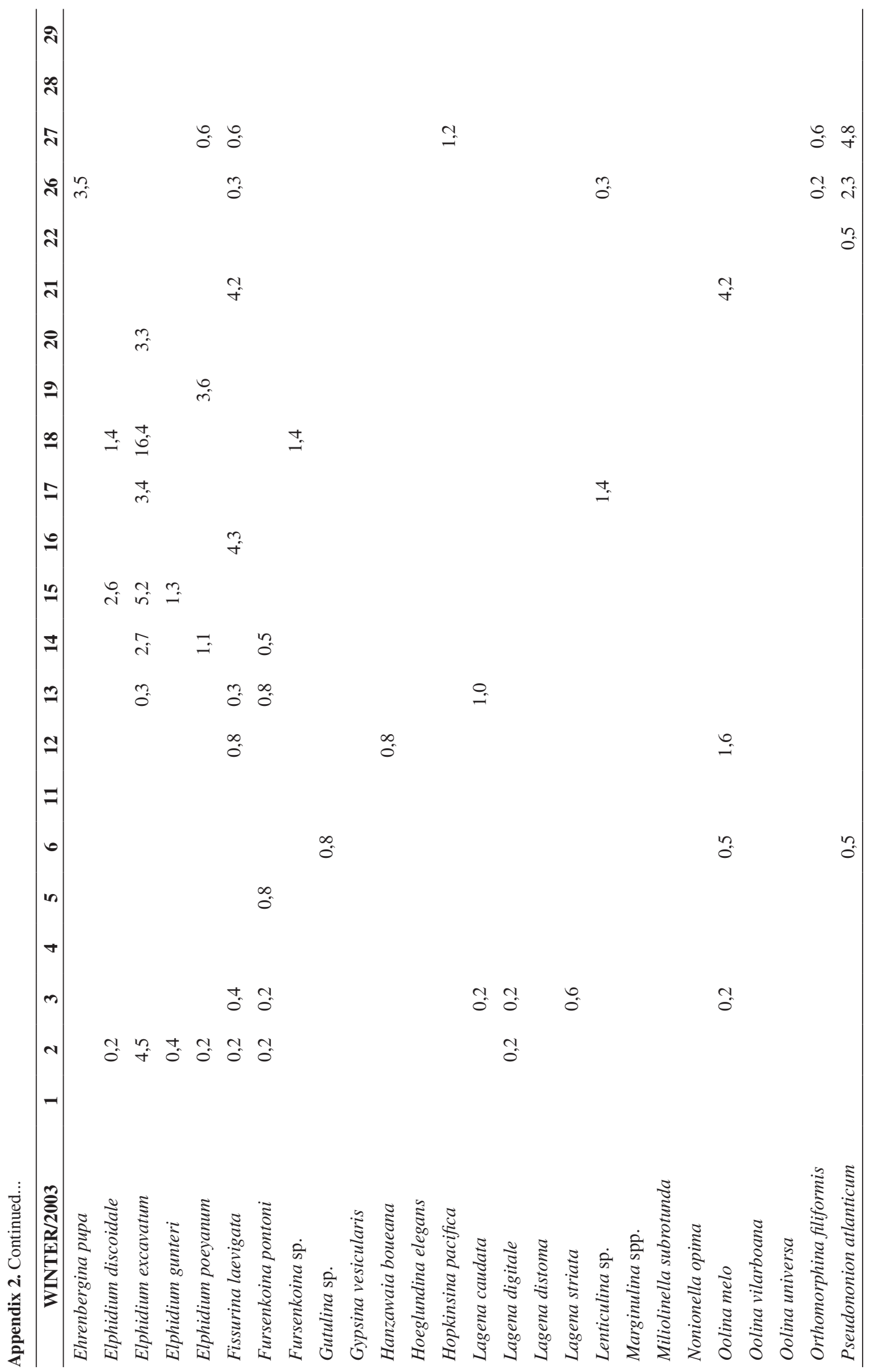


Eichler, PPB. et al.

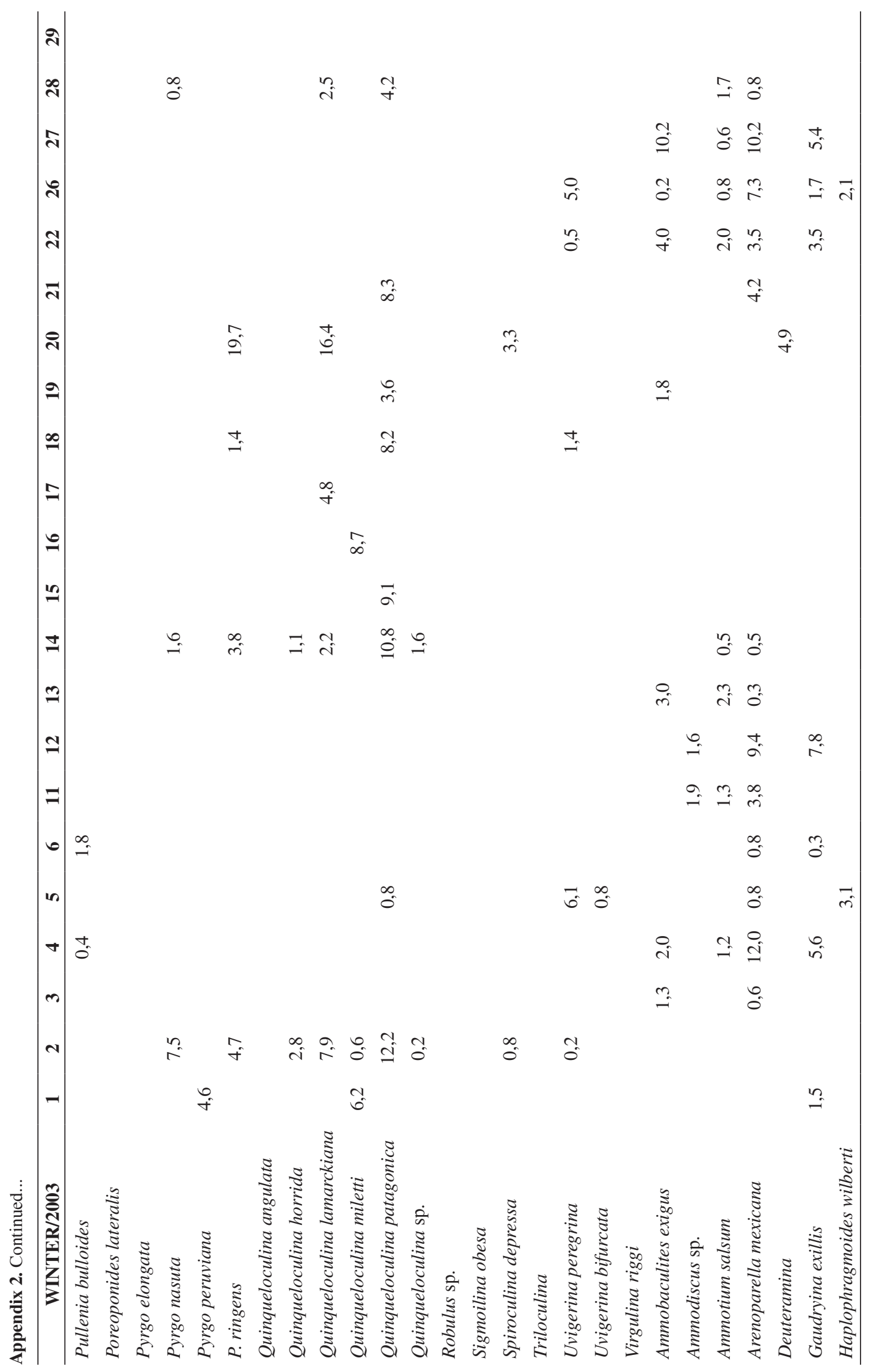




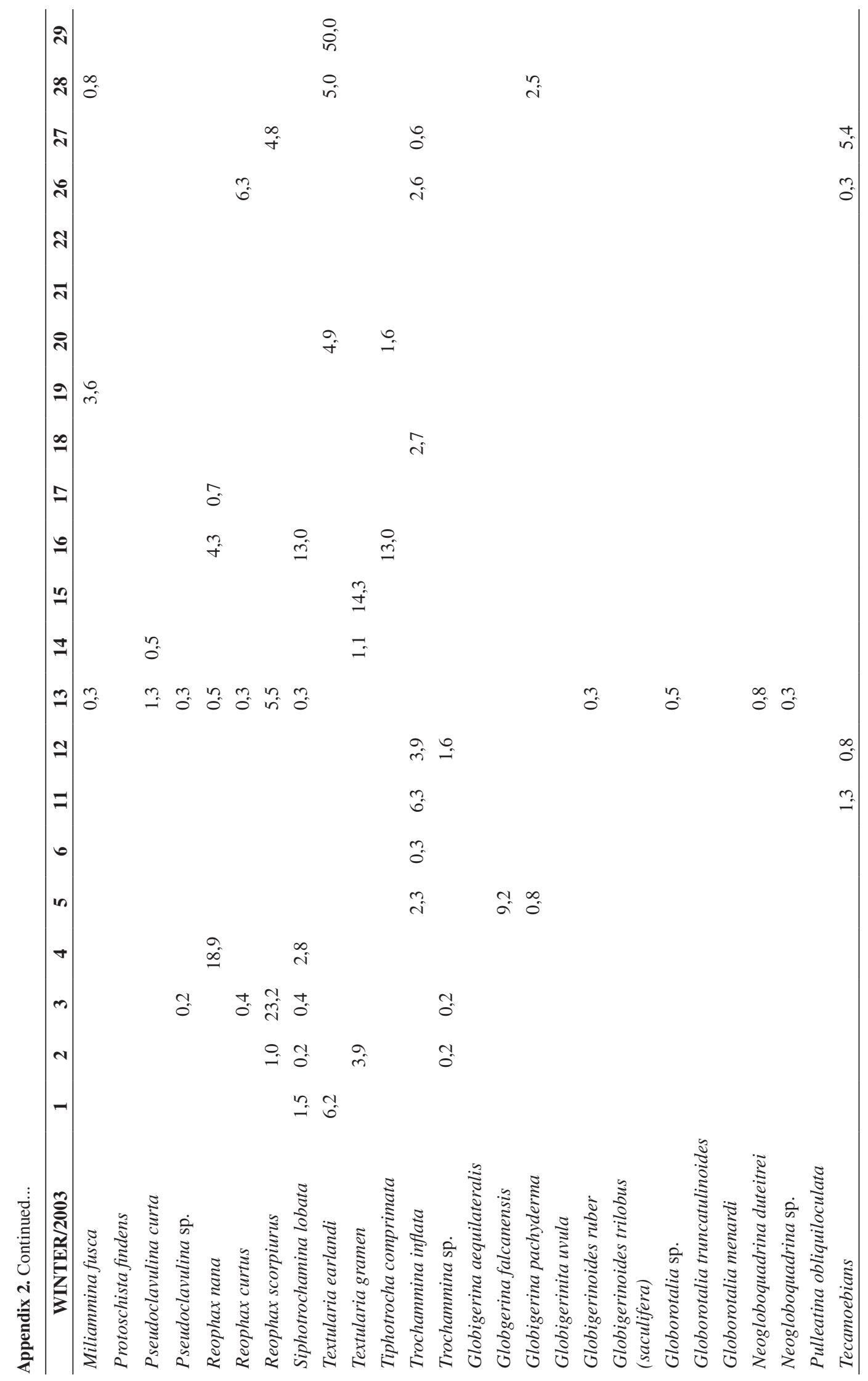




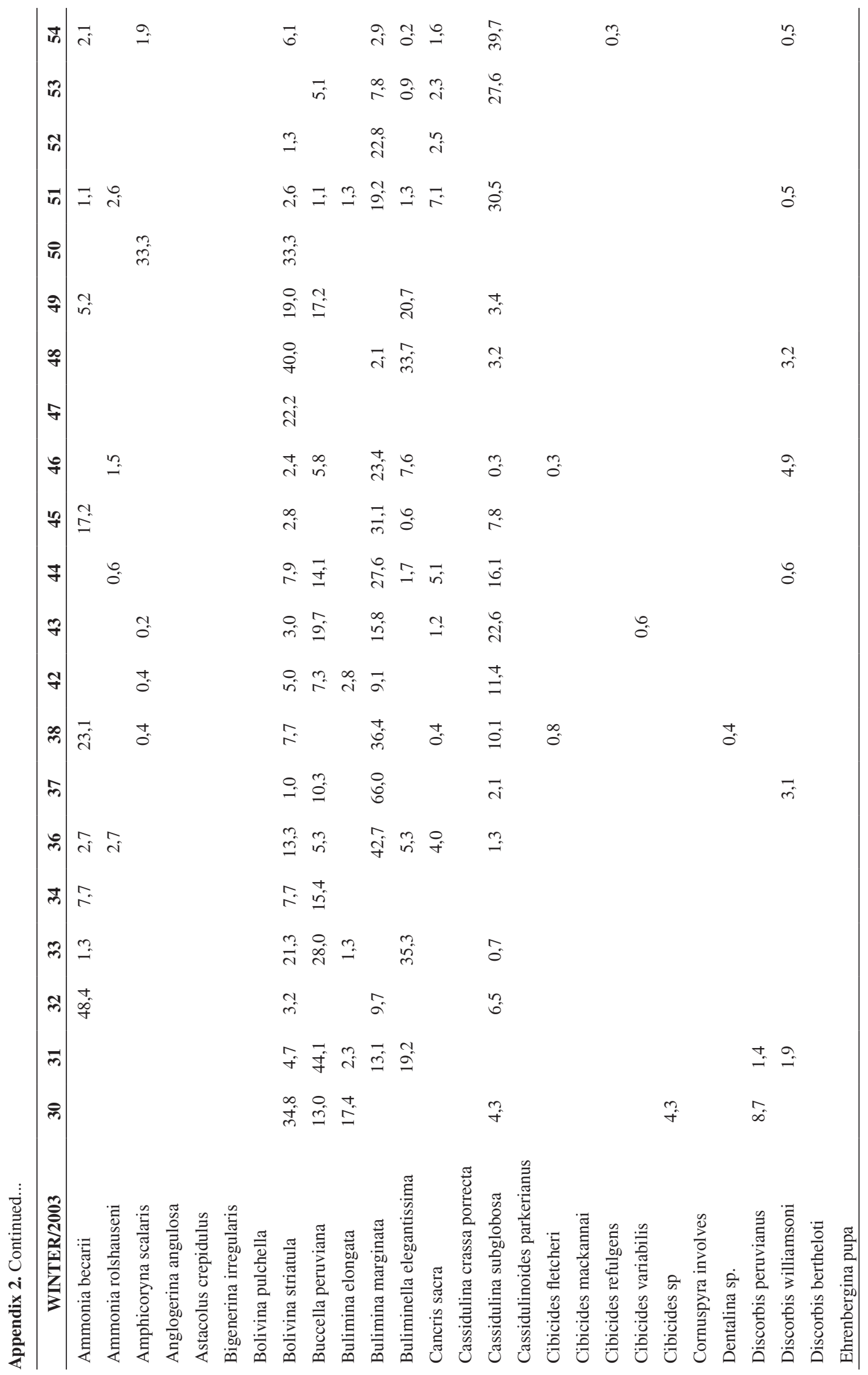


Tracing latitudinal gradient, river discharge and water masses

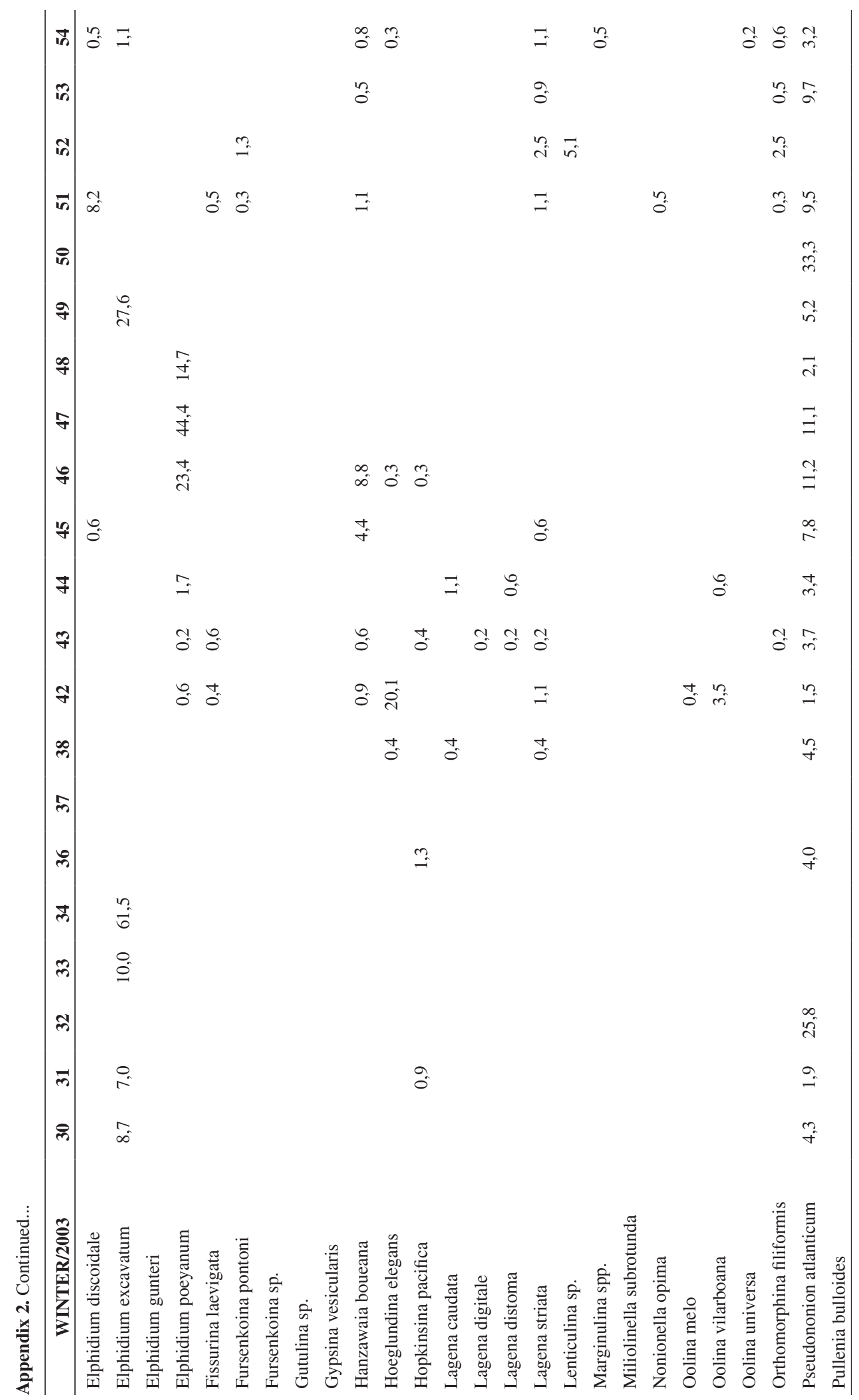


Eichler, PPB. et al.

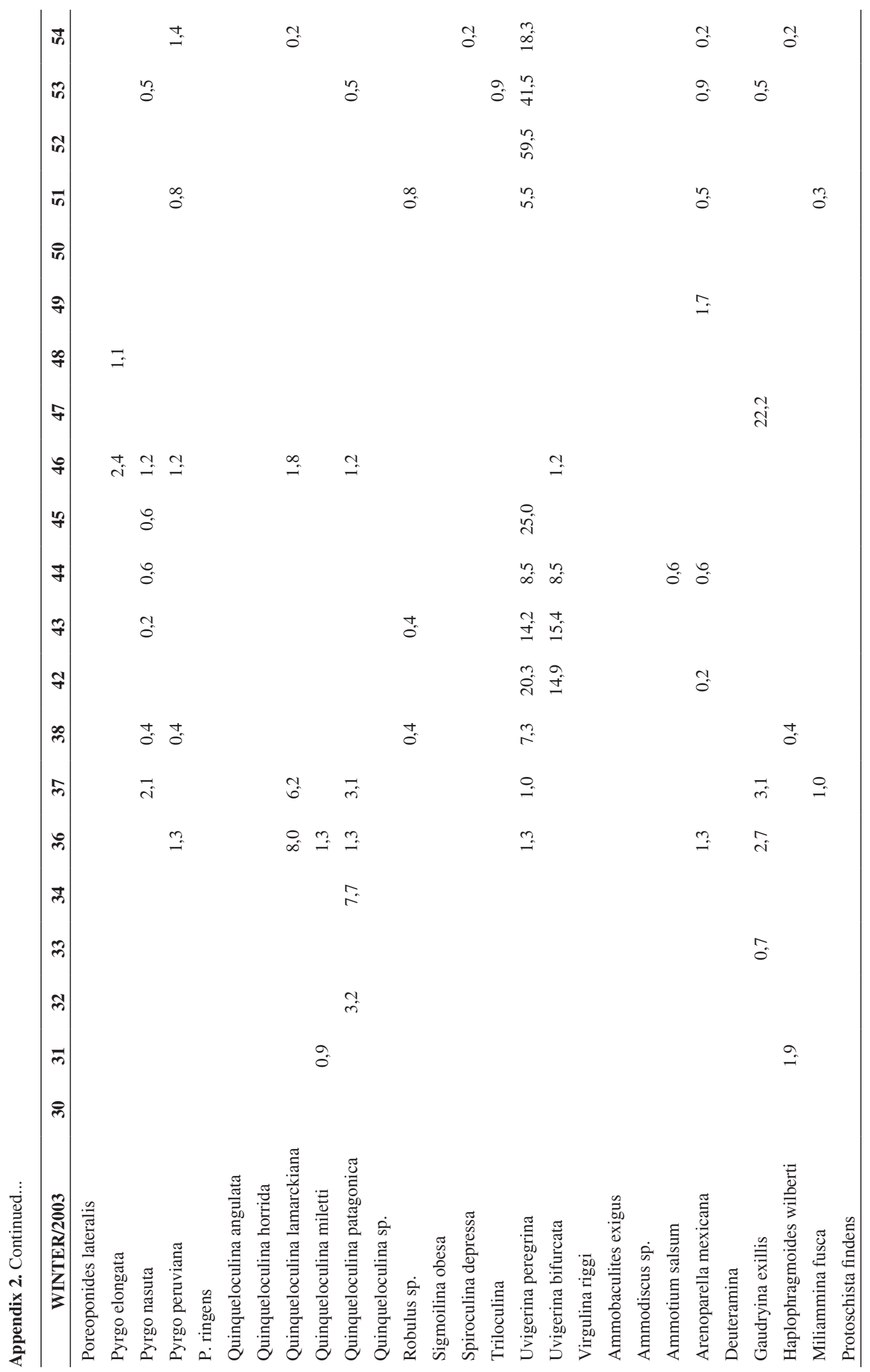


Tracing latitudinal gradient, river discharge and water masses

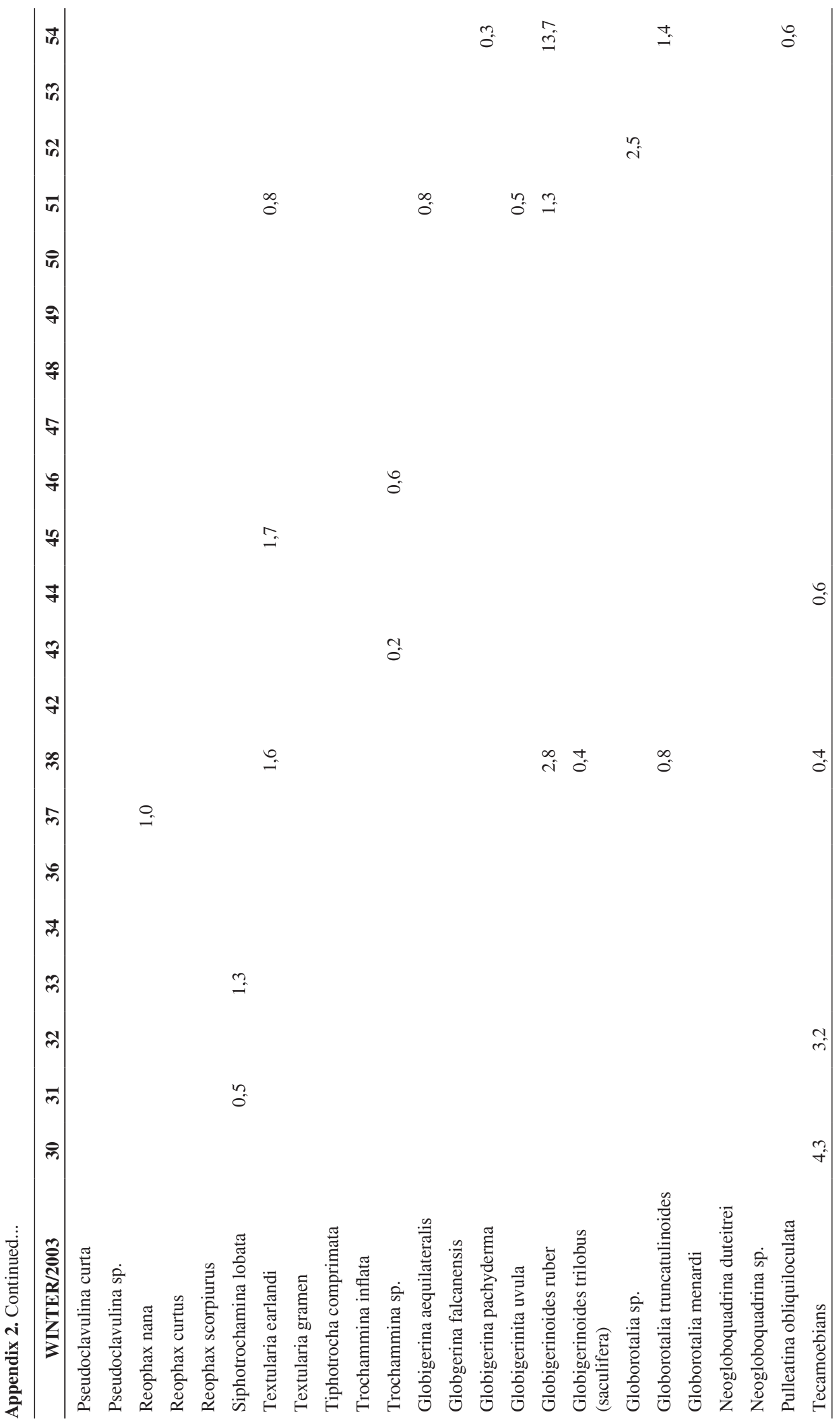

Braz. J. Biol., 2012, vol. 72, no. 3 (suppl.), p. 723-759

755 


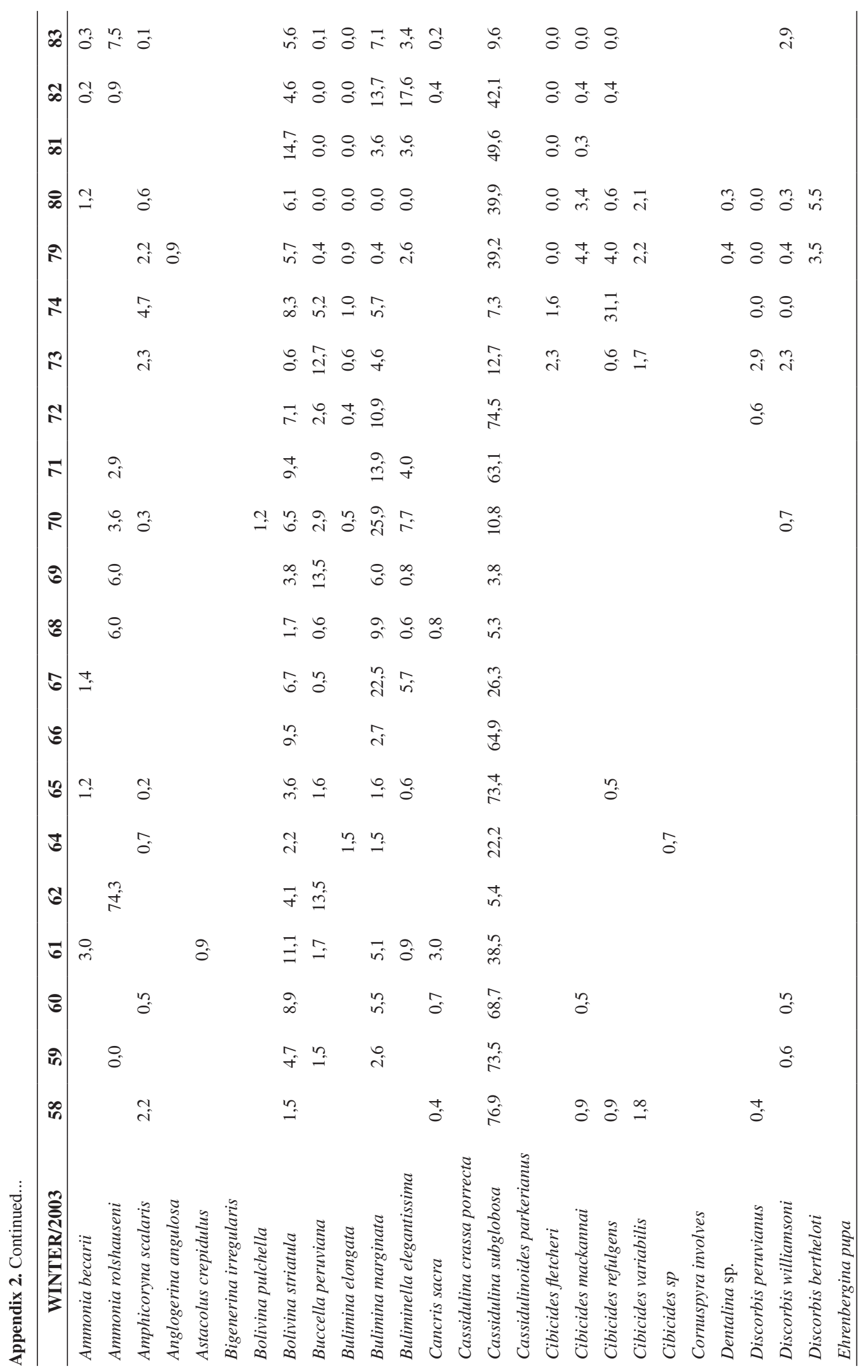


Tracing latitudinal gradient, river discharge and water masses

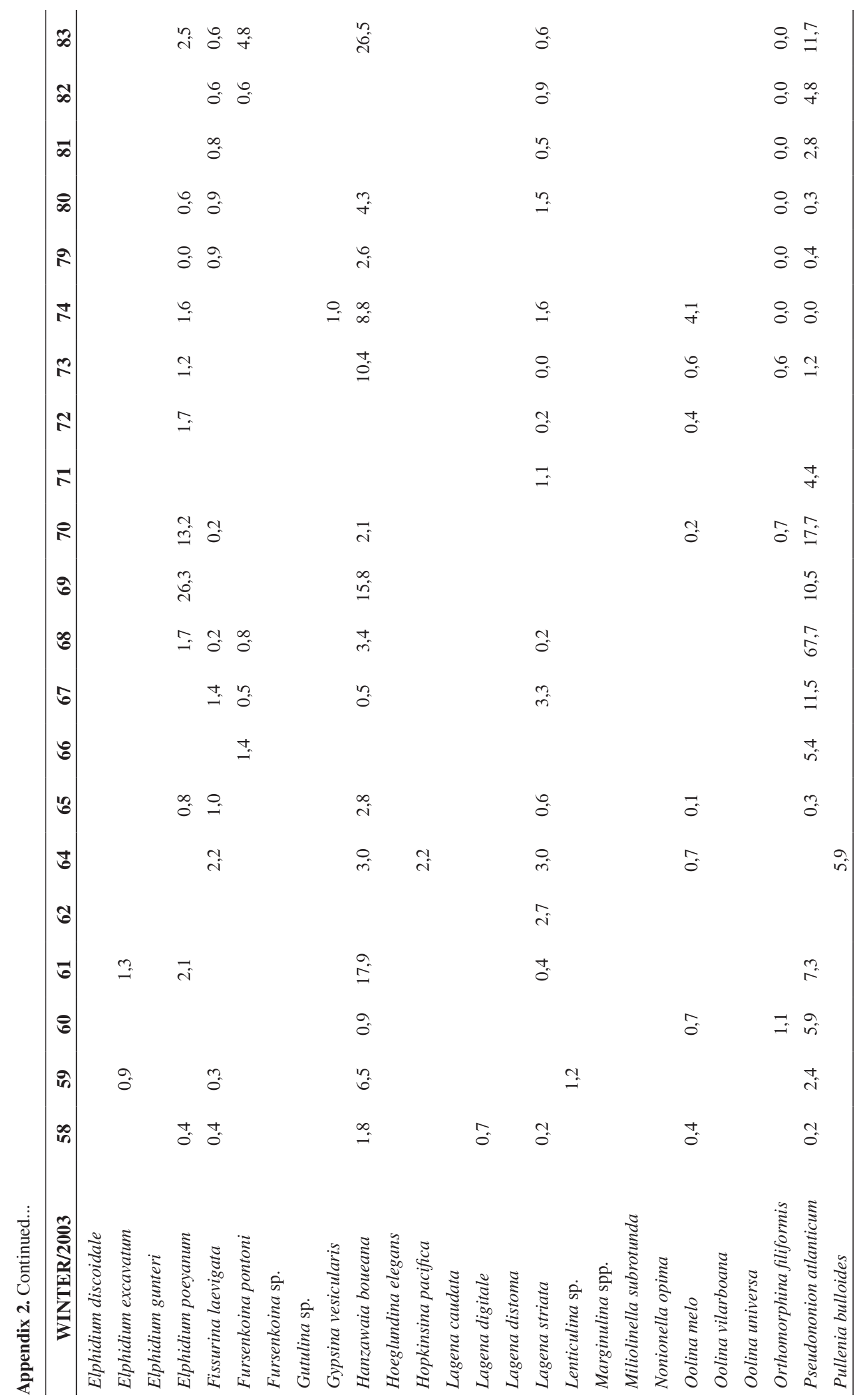


Eichler, PPB. et al.

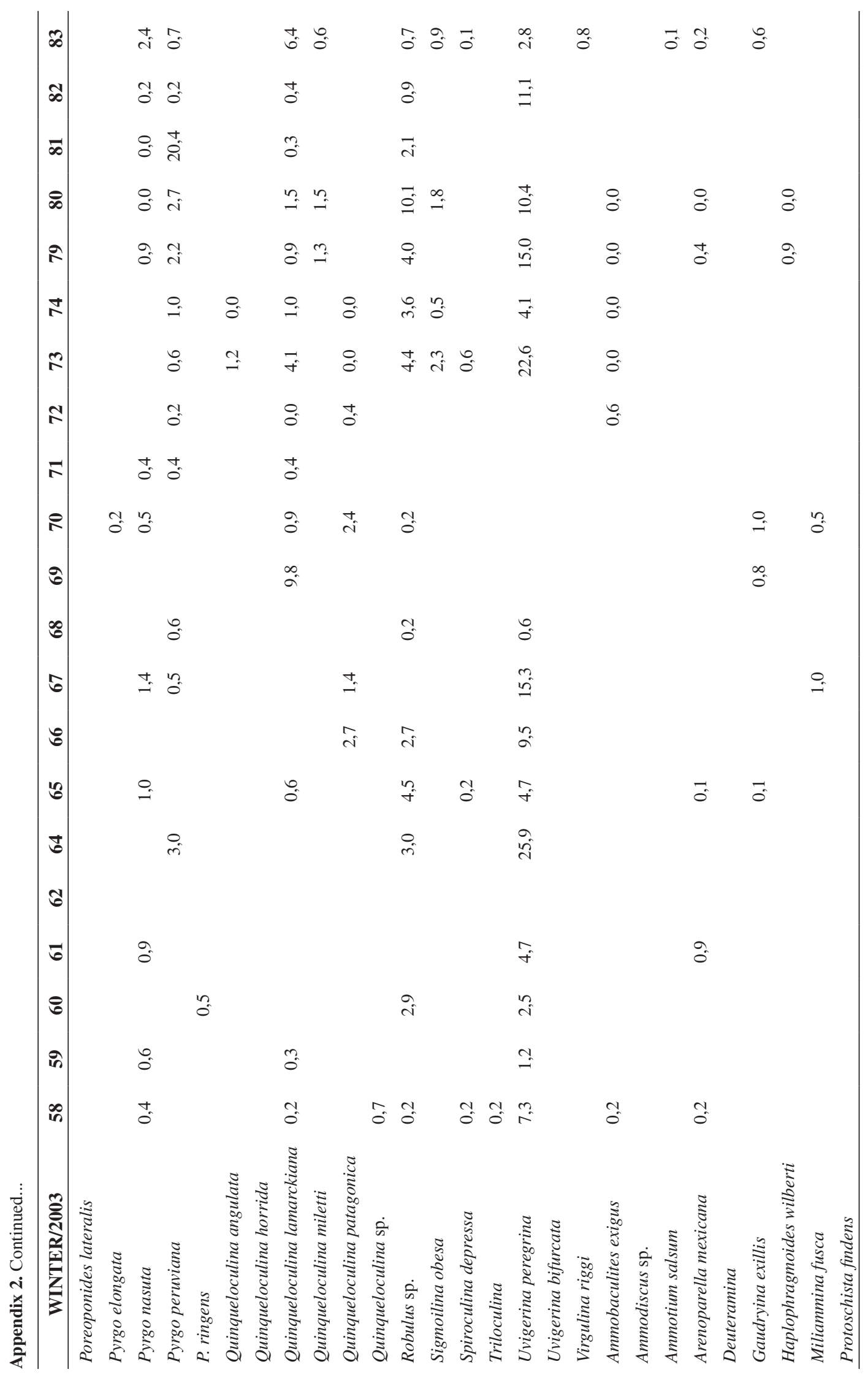


Tracing latitudinal gradient, river discharge and water masses

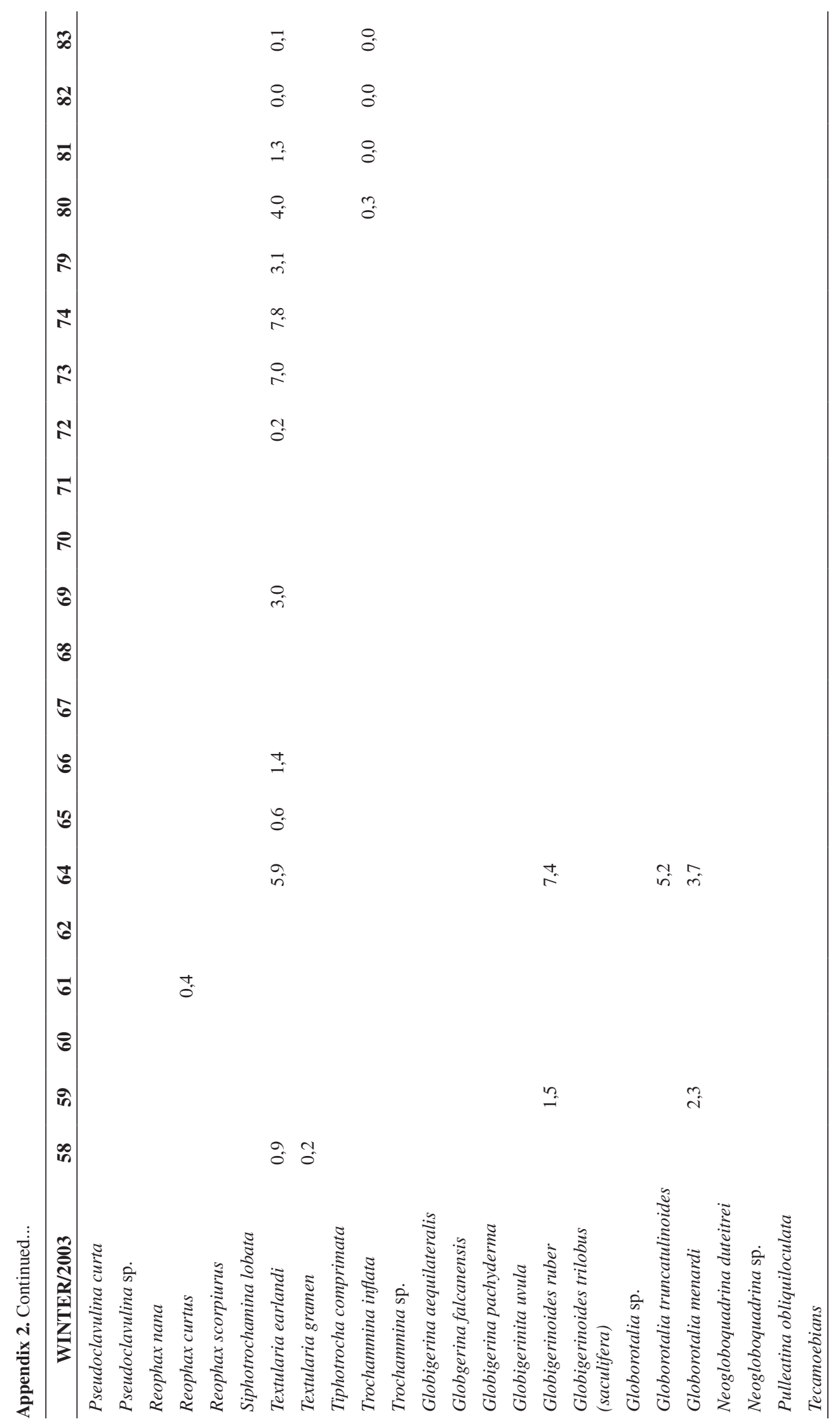

